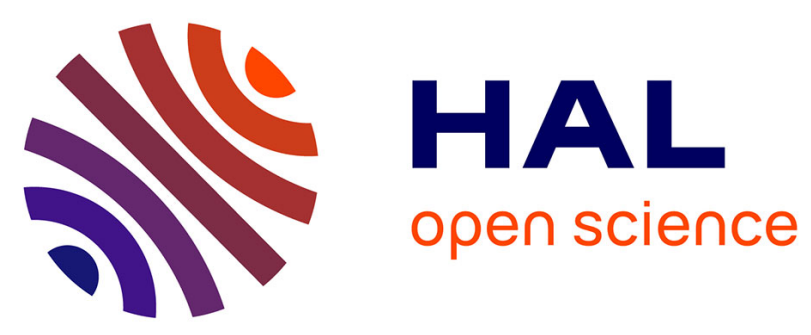

\title{
Gold(I)-Catalysed Asymmetric Hydroamination of Alkenes: A Silver- and Solvent-Dependent Enantiodivergent Reaction
}

\author{
Marc-Antoine Abadie, Xavier Trivelli, Florian Medina, Nathalie Duhal, \\ Mostafa Kouach, Bernhard Linden, Eric Génin, Maxence Vandewalle, Frédéric \\ Capet, Pascal Roussel, et al.
}

\section{To cite this version:}

Marc-Antoine Abadie, Xavier Trivelli, Florian Medina, Nathalie Duhal, Mostafa Kouach, et al.. Gold(I)-Catalysed Asymmetric Hydroamination of Alkenes: A Silver- and Solvent-Dependent Enantiodivergent Reaction. Chemistry - A European Journal, 2017, 23 (45), pp.10777 - 10788. 10.1002/chem.201701301 . hal-01663092

\section{HAL Id: hal-01663092 https://hal.science/hal-01663092}

Submitted on 31 Aug 2020

HAL is a multi-disciplinary open access archive for the deposit and dissemination of scientific research documents, whether they are published or not. The documents may come from teaching and research institutions in France or abroad, or from public or private research centers.
L'archive ouverte pluridisciplinaire HAL, est destinée au dépôt et à la diffusion de documents scientifiques de niveau recherche, publiés ou non, émanant des établissements d'enseignement et de recherche français ou étrangers, des laboratoires publics ou privés. 


\title{
Gold(I) catalysed asymmetric hydroamination of alkenes: a silver and solvent dependent enantiodivergent reaction.
}

\author{
Marc-Antoine Abadie, ${ }^{[a, b]}$ Xavier Trivelli, ${ }^{[c]}$ Florian Medina, ${ }^{[a, b]}$ Nathalie Duhal, ${ }^{[d]}$ Mostafa Kouach, ${ }^{[d]}$ \\ Bernhard Linden, ${ }^{[\mathrm{e}]}$ Eric Génin, ${ }^{[\mathrm{fl}]}$ Maxence Vandewalle, ${ }^{[\mathrm{a}]}$ Frédéric Capet, ${ }^{[\mathrm{a}]}$ Pascal Roussel, ${ }^{[a]}$ Iker Del \\ Rosal, ${ }^{[g]}$ Laurent Maron, ${ }^{[g]}$ Francine Agbossou-Niedercorn ${ }^{\star[a, b]}$ and Christophe Michon ${ }^{*[a, b]}$
}

\begin{abstract}
In the present study, we report the first silver dependent enantiodivergent gold catalysed reaction. The asymmetric intramolecular hydroamination of alkenes catalysed by the combination of a single chiral binuclear gold(l) chloride complex and silver perchlorate can afford both enantiomers of the products by a simple solvent change from toluene to methanol. Such an enantiodivergent reaction is strictly independent of the nature of the catalyst anion or the reaction temperature and displays the same first-order kinetic rate law with respect to substrate concentration in both solvents. Beyond a simple solvent effect, the enantioinversion is controlled by gold-silver chloride adducts which occur only in methanol and allow a dual activation of the reagent. While one single gold atom activates the alkene moiety, the other gold atom forms an oxophilic gold-silver chloride adduct which interacts with the carbamate function. By comparison with toluene which affords $(S)$ enantiomer, this proximal and bimetallic activation allows an opposite stereodifferentiation of the two diastereomeric intermediates during the final protodeauration step and leads therefore to the $(R)$-enantiomer.
\end{abstract}

\section{Introduction}

The hydroamination of unactivated alkenes is the shortest synthetic route to secondary and tertiary amines. ${ }^{[1]}$ For the enantioselective synthesis of optically pure amines, the most studied and privileged hydroamination method is metal catalysis. ${ }^{[1]}$ Throughout recent years, gold catalysts have been successfully applied to various C-C multiple bond substrates like

[a] Dr. M.-A. Abadie, Dr. F. Medina, M. Vandewalle, Dr. F. Capet, Dr. P. Roussel, Dr. F. Agbossou-Niedercorn, Dr. C. Michon, Univ. Lille, CNRS, Centrale Lille, ENSCL, Univ. Artois, UMR 8181 - UCCS Unité de Catalyse et Chimie du Solide, F-59000 Lille, France.

E-mail: christophe.michon@ensc-lille.fr, francine.agbossou@ensc-lille.fr

[b] ENSCL, UCCS-CCM-MOCAH, (Chimie-C7) CS 90108, 59652 Villeneuve d'Ascq Cedex, France.

[c] Dr. X. Trivelli, UGSF CNRS, UMR 8576, Université Lille Nord de France, 59655 Villeneuve d'Ascq Cedex, France.

[d] Dr. M. Kouach, N. Duhal, Plateforme de Spectrométrie de masse, EA 7365 GRITA, Faculté de Pharmacie - Univ. Lille, 3 rue du Professeur Laguesse BP 83 - 59006 Lille Cedex, France.

[e] Dr. B. Linden, Linden ChroMasSpec GmbH Auf dem Berge 25 D28844 Weyhe Germany.

[f] Dr. E. Genin, ThermoFisher Scientific, 16 avenue du Québec - silic 765 Villebon-sur-Yvette, 91963 Courtaboeuf Cedex, France.

[g] Prof. Dr. L. Maron, Dr. I. Del Rosal, Université de Toulouse et CNRS INSA, UPS, CNRS, UMR 5215, LPCNO 135 avenue de Rangueil, 31077 Toulouse, France.

Supporting information for this article is available on the web.

alkynes, alkenes, allenes, and dienes for both intra- and intermolecular hydroamination reactions. ${ }^{[2,3]}$ As high temperatures, long reaction times, and strict conditions are generally required, the gold catalysed hydroamination of alkenes has been less studied in its asymmetric version. ${ }^{[1 p, 3,4]}$ To the best of our knowledge, only seven reports have been published so far on this topic. ${ }^{[4]}$ First, binuclear gold(I) catalysts based on BIPHEP ligands were found to be active for intermolecular hydroamination of ethylene and 1-alkenes with cyclic ureas leading to high yields and enantioselectivities. ${ }^{[4 a]}$ Latter, tropos BIPHEP-binuclear gold(I) species combined with chiral anions were shown to catalyse intramolecular hydroamination of $\mathrm{N}$ alkenyl ureas at room temperature with good yields and average enantioselectivities. ${ }^{[4 \mathrm{~b}]}$ Thereafter, the use of several mononuclear gold(I) complexes based on axially-chiral ligands was reported to catalyse intramolecular hydroamination of $\mathrm{N}$ alkenyl tosylates. Moderate yields and enantioselectivities were obtained at quite high temperatures and reaction times. ${ }^{[4 c]}$ In 2014, Widenhoefer et al. reported the intramolecular hydroamination of $\mathrm{N}$-4-pentenylcarbamates and ureas catalysed by the combination of a mono- or binuclear gold complex and AgOTf (5 mol\%) in methanol. ${ }^{[4 d]}$ While using a binuclear gold(I)(S)-DTBM-MeO-BIPHEP catalyst, average to high yields and enantioselectivities were obtained at room temperature, $0^{\circ} \mathrm{C}$ or $20{ }^{\circ} \mathrm{C}$ within 2 or 3 days of reaction. Besides the axially chiral bidentate BIPHEP ligands, monodentate phosphines derivatised from MOP ligand skeleton led to active mononuclear gold catalysts which allowed quantitative reactions but low enantioselectivities. ${ }^{[4 \mathrm{~d}]}$ At the meantime, following our ongoing interest in hydroamination reactions ${ }^{[5]}$ we recently reported on mononuclear gold(I)- phosphoramidite complexes which led to valuable catalysts for the intramolecular hydroamination of several alkenes at mild temperatures, providing good yields and average enantioselectivities. ${ }^{[4]}$ We subsequently studied various binuclear gold(I)-diphosphine catalysts. When combined with selected silver salts, a binuclear gold(I) chloride species built on a specific SEGPHOS diphosphine ligand proved to perform efficiently the intramolecular hydroamination of alkenes at mild temperatures with high yields and enantioselectivities. ${ }^{[4, g]}$ Interestingly, both enantiomers of the products were obtained through the use of the same chiral gold catalyst by simply switching from toluene to methanol (Scheme 1).

Like many organometallics, most gold complexes require the combined use of silver salts to be activated through abstraction of halides from neutral complexes. In the past years, several groups have reported on the silver salt effects in gold catalysis. ${ }^{[6]}$ Positive or negative impacts on yields and selectivities were observed. 


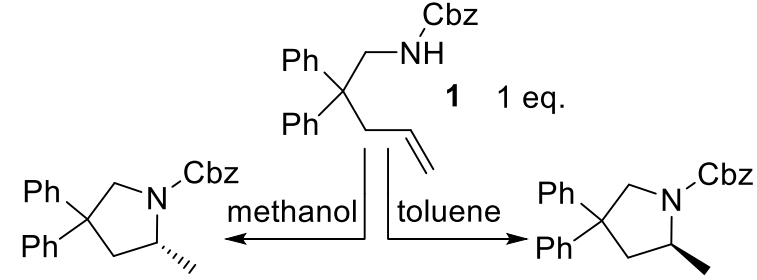

$\begin{array}{lll}(-)-(R)-2 & 1) \mathrm{AuClSMe}_{2}(5.5 \mathrm{~mol} \%) \quad(+)-(S)-2\end{array}$ $61 \%$ yield ligand $(2.7 \mathrm{~mol} \%) \quad 87 \%$ yield $54 \%$ ee $\quad 2) \mathrm{AgClO}_{4}(5 \mathrm{~mol} \%) \quad 68 \%$ ee

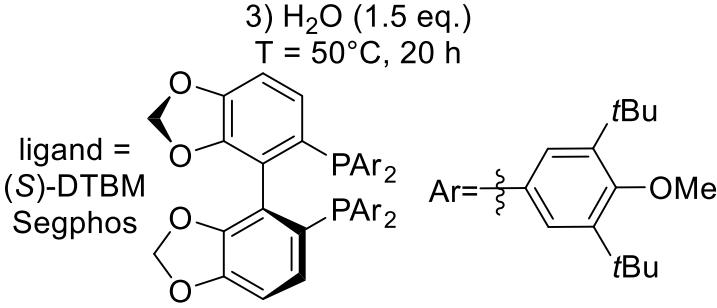

Scheme 1. Enantiodivergent intramolecular hydroamination of alkenes catalysed by gold(I) cationic complex.

Whether the interference of silver and chloride has been highlighted by several bonding modes for cationic monomeric and oligomeric phosphine gold chloride complexes, ${ }^{[7]}$ the catalytic behaviour of such gold-silver chloride species was, to the best of our knowledge, never rationalised before.

Along our studies on gold catalysed hydroamination reactions, we noticed a positive silver effect for binuclear gold(I) catalysts but none for mononuclear ones. ${ }^{[4 \mathrm{e}-\mathrm{g}, 5 \mathrm{c}]}$ Indeed, whether the reaction outcome remained unchanged upon removal of $\mathrm{AgCl}$ by filtration through Celite ${ }^{\mathrm{TM}}$, or PTFE filter, of a phosphoramidite mononuclear gold(I) cationic species prepared prior to the catalysis, a significant decrease of yields and enantioselectivities was observed when a binuclear gold $(I)$ catalyst was filtered in a similar way. Hence, we assumed one gold atom of the binuclear catalyst may interfere positively with silver chloride within the catalytic process depending on the solvent used. Though various enantiodivergent reactions using a single chiral catalyst have been reported, ${ }^{[8]}$ their mechanisms remain not well understood. However, some previous studies demonstrated through kinetic analyses and calculations the origin of solvent-dependent stereodiscrimination was often controlled by an enthalpy-entropy compensation. ${ }^{[9]}$ Regarding gold catalysed enantiodivergent reactions, solvent, temperature or counterion proved to induce the enantioinversion alone or in combination with one another. ${ }^{[10-12]}$ Herein, we report the first silver and solvent dependent enantiodivergent gold catalysed reaction.

\section{Results and Discussion}

The influence of solvents on the enantiodivergent hydroamination of alkenes was studied first (Table 1). Whether coordinative solvents like tetrahydrofurane (THF) and 1,4dioxane led to poor yields (entries 1-2), apolar aromatic solvents allowed the reaction to proceed in high yields and good enantioselectivies for the $(S)$-enantiomer, toluene being the best (entries 3-7). Interestingly, the addition of water to the reaction mixture significantly improved yields and to a lesser extent enantioselectivities (entries 5-7). The combined use of toluene and 1.5 equivalent of water offered the best compromise for yields and enantioselectivity. While using polar solvents, rather mixed results were obtained. Whether 1,1,2,2-tetrachloroethane (TCE) did not allow any reaction (entry 8 ), ethylenecarbonate afforded product 2 in good yield and low enantioselectivity (entry 9). Surprisingly, the use of nitromethane (entry 10) or several alcohols (entries 11-16) resulted in an enantioinversion, $(R)$ enantiomer being obtained in average to high yields. Methanol appeared as the best alcohol solvent affording $(R)-2$ in $54 \%$ ee while using 1.5 equivalent of water (entries 15-17). In addition, we noticed the use of either toluene or methanol led to similar enantioinversions for $\mathrm{N}$-alkenyl $\mathrm{BOC}$, urea and methylester substrates (Table $\mathrm{S} 1$ ).

Table 1. Effect of the solvent on the hydroamination of 1 .

1) $\mathrm{AuClSMe}_{2}$ (5.5 mol\%)

\begin{tabular}{|c|c|c|c|}
\hline \multicolumn{4}{|c|}{$\begin{array}{c}\text { 1) } \mathrm{AuClSMe}_{2} \text { (5.5 mol\%) } \\
\text { Cbz (S)-DTBM Segphos (2.7 mol\%) }\end{array}$} \\
\hline$\sqrt{N}$ & $\begin{array}{l}\text { 2) } \mathrm{AgClO}_{4} \text { (5 mol\%) } \\
\text { 3) } \mathrm{H}_{2} \mathrm{O} \text { (1.5 eq.) }\end{array}$ & \multirow{2}{*}{\multicolumn{2}{|c|}{2}} \\
\hline 1 & $\begin{array}{c}\text { solvent } \\
50^{\circ} \mathrm{C} 20 \mathrm{~h}\end{array}$ & & \\
\hline Entry & Solvent & $\begin{array}{l}\text { Yield } \\
\text { (\%)[a] }\end{array}$ & $\begin{array}{l}\mathrm{Ee} \\
(\%)\end{array}$ \\
\hline 1 & THF & 35 & $21(S)$ \\
\hline 2 & 1,4-dioxane & $<5$ & - \\
\hline 3 & $m$-xylene & 78 & $67(S)$ \\
\hline 4 & Benzene & 90 & $65(S)$ \\
\hline 5 & Toluene & 87 & $68(S)$ \\
\hline 6 & Toluene + no $\mathrm{H}_{2} \mathrm{O}$ & 71 & $63(S)$ \\
\hline 7 & Toluene +10 eq. $\mathrm{H}_{2} \mathrm{O}$ & 94 & $67(S)$ \\
\hline 8 & 1,1,2,2-tetrachloroethane (TCE) & $<5$ & - \\
\hline $9^{[c]}$ & ethylene carbonate & 71 & $18(S)$ \\
\hline 10 & $\mathrm{NO}_{2} \mathrm{Me}$ & $>95$ & $5(R)$ \\
\hline 11 & $t-\mathrm{BuOH}$ & 38 & $1(R)$ \\
\hline 12 & $i-\mathrm{PrOH}$ & 43 & $27(R)$ \\
\hline 13 & $\mathrm{CF}_{3} \mathrm{CH}_{2} \mathrm{OH}$ & 90 & $14(R)$ \\
\hline 14 & Ethanol & 36 & $44(R)$ \\
\hline 15 & Methanol & 61 & $54(R)$ \\
\hline 16 & Methanol + no $\mathrm{H}_{2} \mathrm{O}$ & 76 & $52(R)$ \\
\hline 17 & Methanol / $\mathrm{H}_{2} \mathrm{O}(1 / 1)$ & $<5$ & - \\
\hline
\end{tabular}

We next focused on the influence of the anion and the dehalogenating cation on the yield and enantiomeric excess (Table 2). Among the various salts screened, perchlorate and tetrafluoroborate anions appeared to be the most appropriate (entries 1-2, 9-10). When product 2 was formed, the enantioselectivity and the nature of the ion pairing ${ }^{[13]}$ were unrelated under our reaction conditions. The catalyst proved to be unreactive when associated with $\mathrm{BArF}_{24}$ anion or chiral TRIP phosphate, even with stronger reaction conditions (entries 1622). Finally, the chloride abstraction of the gold(I) pre-catalyst and therefore the reaction needed a silver cation to proceed. 
Table 2. Effect of the anion on the reaction of 1 .

\begin{tabular}{|c|c|c|c|c|}
\hline$\underbrace{-N^{\prime}}$ & $\begin{array}{l}1) \\
(S)-D T\end{array}$ & $\begin{array}{l}\mathrm{ISMe}_{2} \text { (5. } \\
\text { Segphos } \\
\mathrm{AgX} \mathrm{(5} \mathrm{m} \\
\mathrm{H}_{2} \mathrm{O}(1.5\end{array}$ & $\begin{array}{l}\text { nol\%) } \\
.7 \text { mol\%) } \\
\%) \\
.)\end{array}$ & 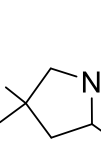 \\
\hline $\begin{array}{c}1 \\
1 \mathrm{eq} .\end{array}$ & & $\begin{array}{r}\text { solvent } \\
50^{\circ} \mathrm{C}, 20\end{array}$ & & 2 \\
\hline Entry & $\mathrm{AgX}$ & Solvent & Yield (\%) ${ }^{[a]}$ & $\operatorname{Ee}(\%)^{[b]}$ \\
\hline 1 & $\mathrm{AgClO}_{4}$ & Toluene & 87 & $68(S)$ \\
\hline 2 & $\mathrm{AgClO}_{4}$ & Methanol & 61 & $54(R)$ \\
\hline 3 & AgOTf & Toluene & 21 & $67(S)$ \\
\hline 4 & AgOTf & Methanol & 65 & $58(R)$ \\
\hline 5 & AgOTs & Toluene & 0 & - \\
\hline 6 & AgOTs & Methanol & 15 & $54(R)$ \\
\hline 7 & $\mathrm{AgSbF}_{6}$ & Toluene & $>95$ & $48(S)$ \\
\hline 8 & $\mathrm{AgSbF}_{6}$ & Methanol & 86 & $52(R)$ \\
\hline 9 & $\mathrm{AgBF}_{4}$ & Toluene & $>95$ & $62(S)$ \\
\hline 10 & $\mathrm{AgBF}_{4}$ & Methanol & 49 & $55(R)$ \\
\hline $11^{[c]}$ & $\mathrm{AgNTf}_{2}$ & Toluene & 61 & $41(S)$ \\
\hline 12 & $\mathrm{AgNTf}_{2}$ & Methanol & 64 & $54(R)$ \\
\hline 13 & $\mathrm{KNTf}_{2}$ & Toluene & 0 & - \\
\hline 14 & $\mathrm{KNTf}_{2}$ & Methanol & 0 & - \\
\hline $15^{[d]}$ & AgPNB & Toluene & 0 & - \\
\hline $16^{[\mathrm{e}, \mathrm{f}]}$ & $(R)$-AgTriP & Toluene & 0 & - \\
\hline $17^{[f, g]}$ & $(R)$-AgTriP & Methanol & 17 & $53(R)$ \\
\hline $18^{[\mathrm{e}, \mathrm{f}]}$ & (S)-AgTriP & Toluene & 0 & - \\
\hline $19^{[f, g]}$ & (S)-AgTriP & Methanol & 10 & $52(R)$ \\
\hline $20^{[\mathrm{h}]}$ & $\mathrm{AgBArF}_{24}$ & Toluene & 10 & $5(S)$ \\
\hline $21^{[\mathrm{h}]}$ & $\mathrm{NaBArF}_{24}$ & Toluene & 0 & - \\
\hline $22^{[\mathrm{h}]}$ & $\mathrm{NaBArF}_{24}$ & Methanol & 0 & - \\
\hline
\end{tabular}

[a] measured by ${ }^{1} \mathrm{H}$ NMR and average of 2 runs. [b] From HPLC. [c] NTf trifluoromethanesulfonimide. [d] PNB: paranitrobenzoate. [e] same result at $100{ }^{\circ} \mathrm{C}$ for 67 h. [f] TriP: 3,3'-bis(2,4,6-triisopropylphenyl)-1,1'-binaphthyl-2,2'diyl-phosphate. [g] at $65^{\circ} \mathrm{C}, 96 \mathrm{~h}$. [h] BArF 24 : tetrakis[(3,5trifluoromethyl)phenyl]borate.

Table 3. Effect of the reaction temperature on the enantioselectivity of 2.

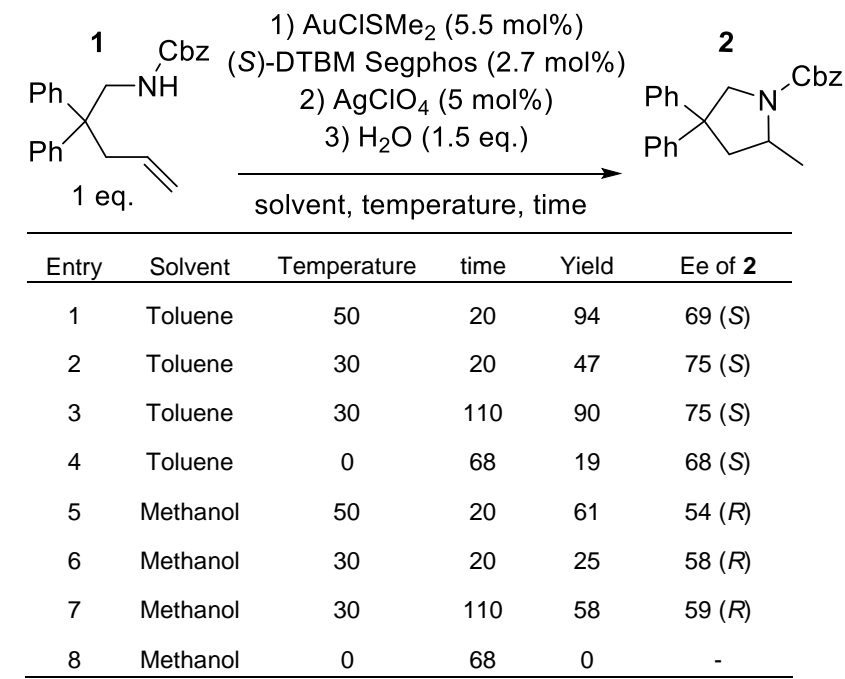

[a] From ${ }^{1}$ H NMR. [b] From HPLC.

Furthermore, we noticed any modification of the reaction procedure $^{[6 \mathrm{e}]}$ resulted in a significant fall-off in yields and a slight decrease of the enantioselectivity. The same trend was observed when catalyst was filtered through a PTFE filter before the reaction (Table S2).
Regarding the effect of the reaction temperature on enantioselectivity, the hydroamination reactions in toluene and methanol were significantly slowed down or inhibited by decreasing the temperature to 30 and $0^{\circ} \mathrm{C}$ without any further inversion of the enantioselecivity (Table 3 ). Through kinetic analyses in both solvents, we observed the same first-order kinetic rate law with respect to substrate concentration in methanol and toluene at $50^{\circ} \mathrm{C}$ (Figures S1-S5). Moreover, by using deuterated methanol, we observed a strong isotopic effect: $\mathrm{t}=20 \mathrm{~h}, 25 \%$ conv. in $\mathrm{MeOH}-\mathrm{d}^{4} / 61 \%$ conv. in $\mathrm{MeOH}$. Though a deuterium-proton exchange between the methanol and the amine was likely to proceed during the reaction, the steps involving a proton migration/transfer appeared as the rate limiting ones. ${ }^{[14]}$ Furthermore, no non-linear effects were observed (Figure 1) and enantiomeric excesses proved to be stable along time (Figure 2).

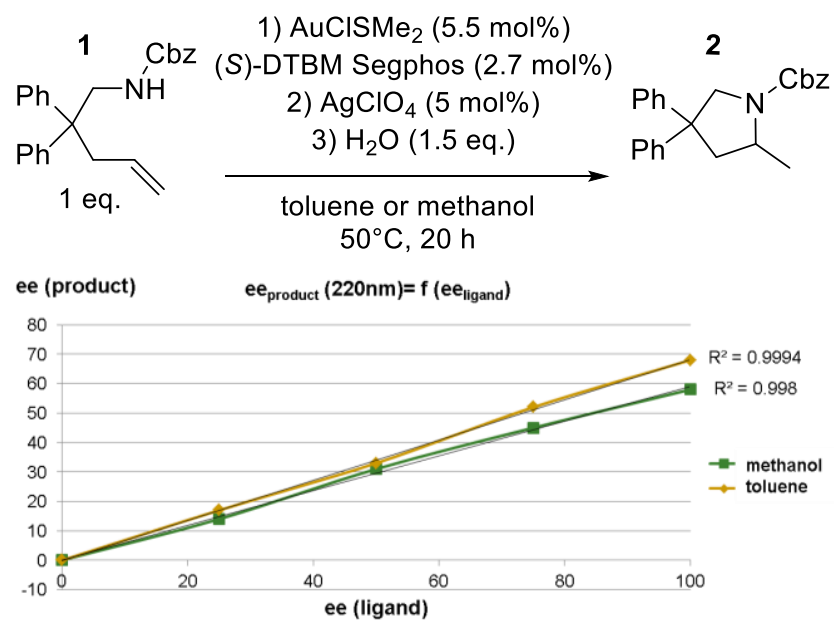

Figure 1. Study of non-linear effects on the hydroamination of $\mathbf{1}$.

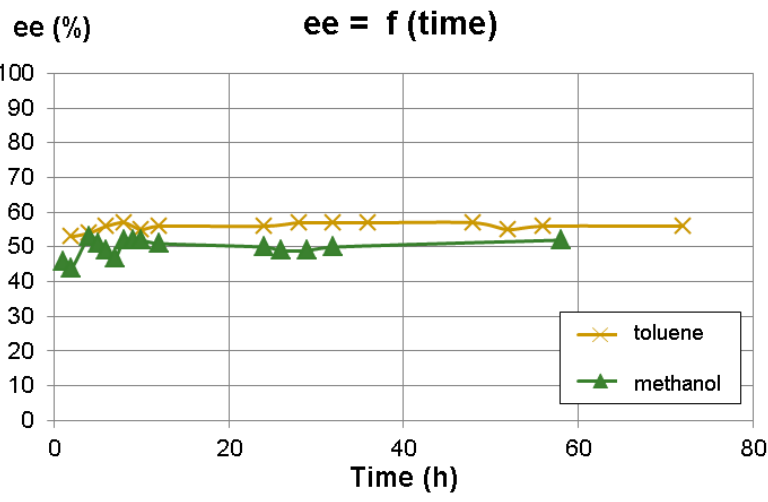

Figure 2 Stability of enantiomeric excess of 2 along time.

Though the structure of the catalyst resting state was not confirmed, we could consider the nuclearity of the gold active species remained unchanged during the whole catalytic process ${ }^{[15]}$ and excluded also any involvement of an in-situ kinetic resolution. ${ }^{[16]}$ Finally, in spite of previous examples in the field of gold catalysis, ${ }^{[4 c, 17,18]}$ our results ruled out the contribution of anion and cation $\pi$ interactions ${ }^{[17-20]}$ between the catalyst and toluene along the enantiodivergent reaction.

At that stage, we focused again on the reactivity of the present gold catalysed hydroamination reaction and studied a series of control experiments through the use of several 
additives (Table 4). First, we performed control experiments in order to check the activity of monocationic gold complexes (entries 2,3). While the enantioselectivities decreased slightly, yields in product 2 were much lower using monocationic binuclear complex (entry 2) or cationic mononuclear complex (entry 3 ) instead of the dicationic binuclear complex (entry 1). Whether the reaction was not catalysed by $\mathrm{AgClO}_{4}$ itself in toluene, a switch to methanol led to the cyclised amine 2 in a good yield (entries 1,4,5). However, because gold(I) cationic catalyst was formed prior to the addition of the reagent, any background reaction catalysed by $\mathrm{AgClO}_{4}$ was rather unlikely (see experimental section). We next observed the reaction could be stopped by the addition of an inorganic base like $\mathrm{Cs}_{2} \mathrm{CO}_{3}$ (entry 8). However, the use of a non-coordinative base like 2,6-di-tertbutyl-pyridine didn't have any effect (entry 9). That trend was confirmed by the addition of a proton trap like $\mathrm{PhSi}(\mathrm{Me})_{3}$ (entry 7) which didn't alter the reaction course. A last control experiment proved the reaction was not catalysed by perchloric acid (Scheme 2). Hence, the presence of free protons in the reaction medium was here unlikely. However, the use of an alcohol along with a cationic binuclear gold complex was reported by Toste et al. ${ }^{[21]}$ to generate an acidic species which catalysed the hydroamination reaction of 4,6-heptadienyl sulfonamides following a Brønsted acid catalysed pathway. We performed a series of reactions by adding 1.5 equivalents of an alcohol to the reaction mixture in toluene (entries 10-18). Depending on the nature of the alcohol used, the yields could be improved, but no global trend was noticed. Enantioselectivities were either stable or reduced and no enantioinversion were observed. Finally, the use of $(+)$ phenylethanol, (-)-menthol or methanol increased slightly the ee values to $67 \%$ ee, whereas yields were respectively 88,67 , and $97 \%$ (entries 11, 12, 18). On the basis of these results, we concluded any Brønsted acid catalysis ${ }^{[21]}$ was unlikely.

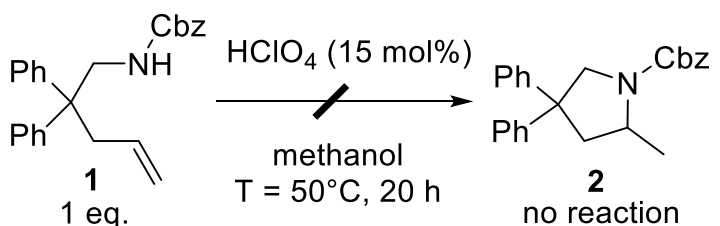

Scheme 2. Control experiments regarding the use of $\mathrm{HClO}_{4}$ as catalyst for the hydroamination of aminoalkene 1

Table 4. Effect of additives on the hydroamination of aminoalkene 1.

1) $\mathrm{AuClSMe}_{2}(5.5 \mathrm{~mol} \%)$

(S)-DTBM Segphos $(2.7 \mathrm{~mol} \%)$

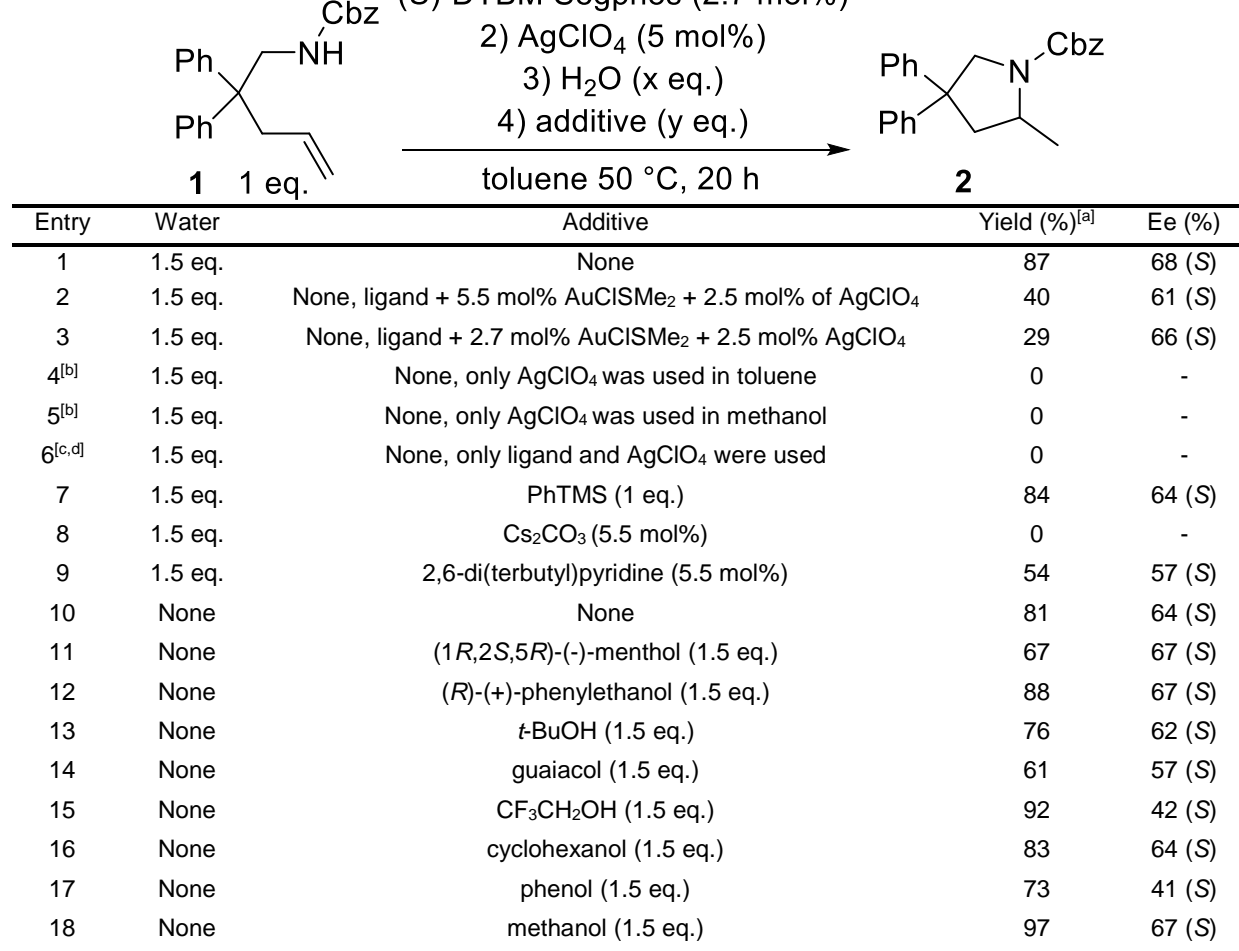

[a] measured by ${ }^{1} \mathrm{H}$ NMR. [b] performed without ligand and $\mathrm{AuCISMe}_{2}$. [c] performed without $\mathrm{AuCISMe}_{2}$. [d] same result in methanol. 
In order to define the bonding mode of our cationic gold(I) species in solution, DOSY ${ }^{1} \mathrm{H}$ NMR experiments were performed on several gold catalysts using palladium complexes as references (Table 5). We found a good agreement between diffusion coefficient $\mathrm{D}$ and hydrodynamic radius $\mathrm{rH}$ of all species. This therefore confirmed the presumed nuclearity and coordination of our catalysts, i.e. two gold atoms coordinated to one diphosphine ligand, and tended to prove any chloride and/or silver bridged species ${ }^{[6 \mathrm{~d}-\mathrm{e}]}$ was unlikely. Indeed, compounds with higher molecular volumes and weights would have displayed lower diffusion coefficient $D$ and higher hydrodynamic radius $\mathrm{rH}$. As water was required in the catalytic medium, ${ }^{[4 \mathrm{~g}]}$ we followed by NMR the reaction of substrate $\mathbf{1}$ with a stoichiometric amount of pre-formed gold complex $\mathbf{3 a}$ in order to check if $\mathbf{3 a}$ was likely to be hydrolysed or not. ${ }^{[22]}$ NMR analyses of aliquots showed unchanged ${ }^{31} \mathrm{P}$ spectra were obtained along all the reaction and no hydrate or hydroxide species were present on ${ }^{1} \mathrm{H}$ spectra (Figures S2-S5), suggesting a strong Brønsted basic gold species was not observed at the NMR time scale and was rather unlikely to be formed. ${ }^{[22 \mathrm{c}]}$

Table 5. Results of DOSY ${ }^{1} \mathrm{H}$ NMR experiments.<smiles>[X][M]P([R17])c1ccc2c(c1-c1c(P[Y12])ccc3c1OCO3)OCO2</smiles>

3a $(R) \mathrm{M}=\mathrm{Au}, \mathrm{X}=\mathrm{ClO}_{4}$ 3b $(R) \mathrm{M}=\mathrm{Au}, \mathrm{X}=\mathrm{BF}_{4}$ 3c $(R) \mathrm{M}=\mathrm{Au}, \mathrm{X}=\mathrm{Cl}$

\begin{tabular}{lcc}
\hline \multicolumn{1}{c}{ Compound } & $\mathrm{D}\left({ }^{1} \mathrm{H}\right)\left(10^{-10} \mathrm{~m}^{2} \mathrm{~s}^{-1}\right)$ & $\mathrm{rH}(\AA)$ \\
\hline (S)-DTBM-Segphos & 5.03 & 8.1 \\
(R) 3a & 4.98 & 8.2 \\
(R) 3b & 4.85 & 8.4 \\
(R) 3c & 4.96 & 8.2 \\
(R) 4a & 4.91 & 8.3 \\
(R) 4b & 4.96 & 8.2 \\
\hline
\end{tabular}

At the solid state, the structure of pre-catalyst $3 c$ and catalyst $\mathbf{3 b}$ were confirmed by $\mathrm{X}$-ray diffraction analysis (Figures 3 , S6-S7). The data were refined using a rigid body approach because tButyl substituents were disordered. For complex $\mathbf{3 b}$, anions, i.e. tetrafluoroborate here, proved to be coordinated to the gold atoms which were not bound to each other being 4.390(19) $\AA$ apart. Hence, by using weakly coordinative tetrafluoroborate anions, complex $\mathbf{3 b}$ could be considered as a neutral species like it was previously observed for other complexes with $\mathrm{NTf}_{2}$ anion. ${ }^{[23]}$ We measured for $\mathbf{3 b}$ a molecular radius of 8.989 (19) $\AA$ (Figures 3,S6) which was close from its $\mathrm{rH}$ value calculated from the DOSY ${ }^{1} \mathrm{H}$ NMR experiments. On the whole, the molecular structure of the gold(I) binuclear complexes was confirmed, two gold atoms being coordinated to one DTBM Segphos diphosphine ligand.

The structure of gold perchlorate catalyst $3 \mathbf{3 a}$ was also studied at the solid state. Whether no crystals were obtained when complex 3a was prepared in toluene, it was isolated and characterised by liquid NMR as well as elemental analysis on solids without any doubt. However, X-ray diffraction analyses on crystals obtained from $\mathbf{3 a}$ in methanol-diethyl ether mixtures revealed different species which were likely to arise out of a partial decomposition of 3a (Scheme 3, Figures 4-5 and S8-S10). Among the several possible mono- and dicationic complexes, species $\mathbf{3 d}$ and $\mathbf{3 e}$ were observed by $\mathrm{X}$-ray diffraction.

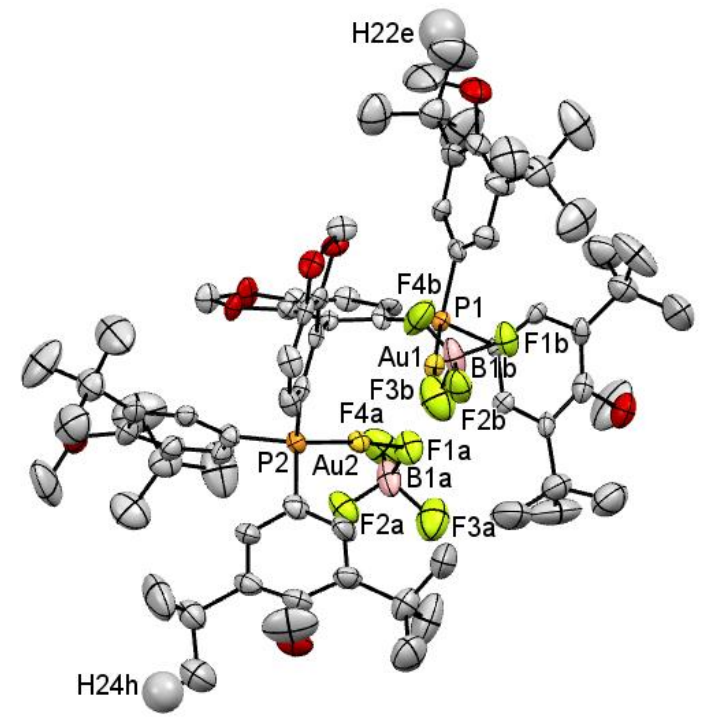

Figure 3. Molecular structure of catalyst $\mathbf{3 b}$ at the solid state. Thermal ellipsoids are shown at the $50 \%$ probability level. Hydrogens atoms and 2 molecules of toluene were omitted for clarity. Selected bond lengths $(\AA)$ : Au1Au2 4.390(19), P1-Au1 2.213(2), P2-Au2 2.205(2), Au1-F3b 2.101(15), Au2F1a 2.095(15). CCDC 995301.

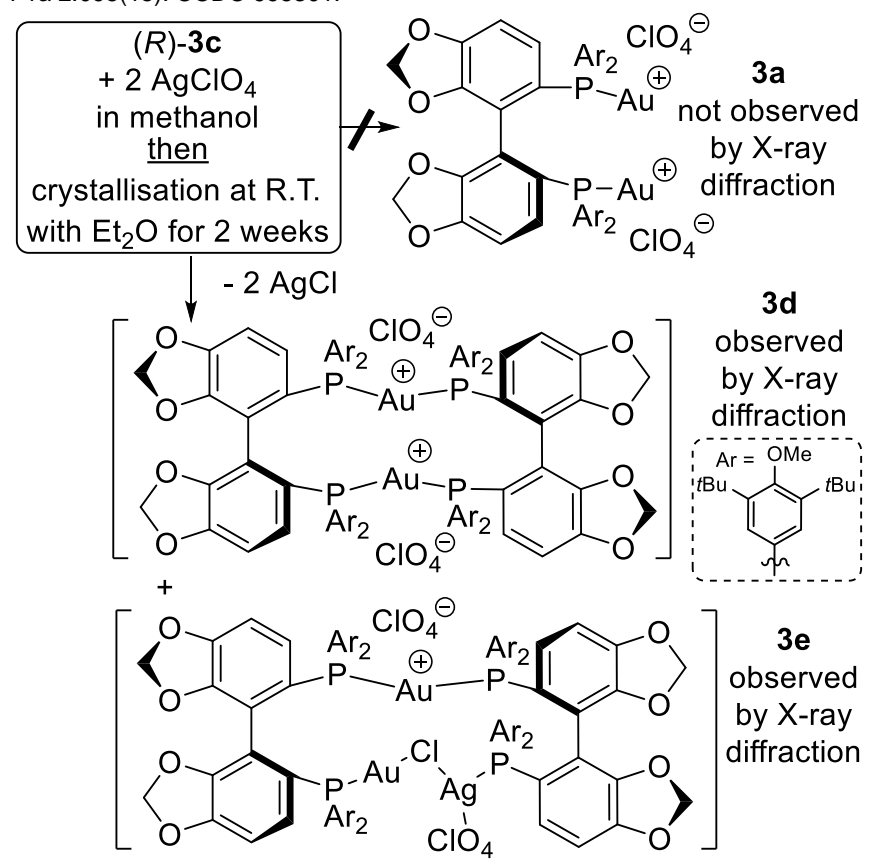

Scheme 3. Crystallisation in methanol of gold(I) cationic complexes $\mathbf{3 d}$ and $\mathbf{3 e}$. 


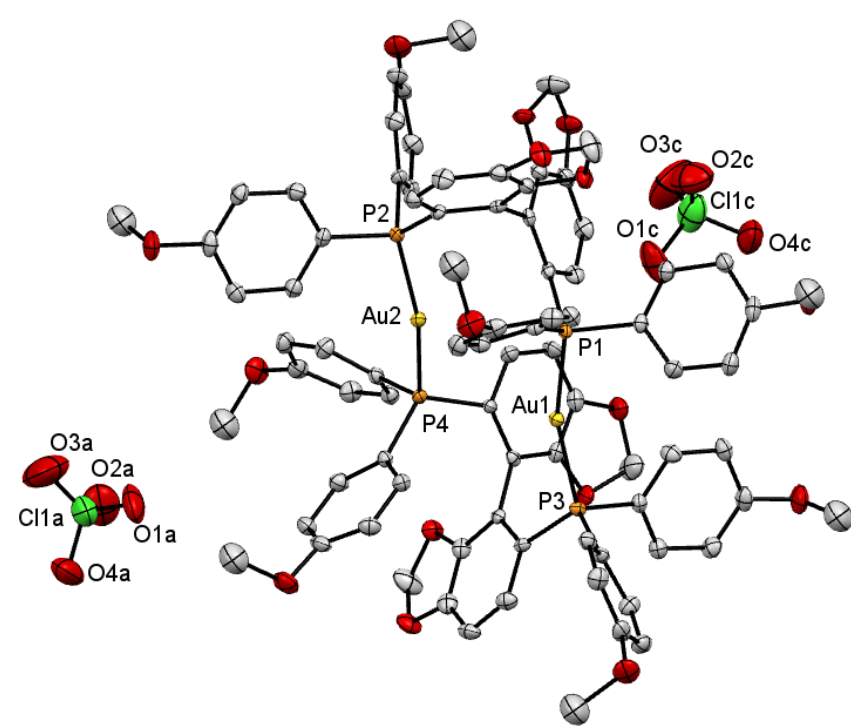

Figure 4. Molecular structure of complex $\mathbf{3 d}$ at the solid state. Therma ellipsoids are shown at the $50 \%$ probability level. Hydrogens atoms, $t \mathrm{Bu}$ groups and a disorder on one of the $\mathrm{ClO}_{4}$ anions were omitted for clarity. Selected bond lengths (Å): Au1-Au2 3.930(19), P1-Au1 2.318(3), P2-Au1 2.320(3), P3-Au2 2.311(2), P4-Au2 2.301(3). CCDC $1539521\left(\mathrm{ClO}_{4}\right)$ and $\operatorname{CCDC} 1539523\left(\mathrm{SbF}_{6}\right)$

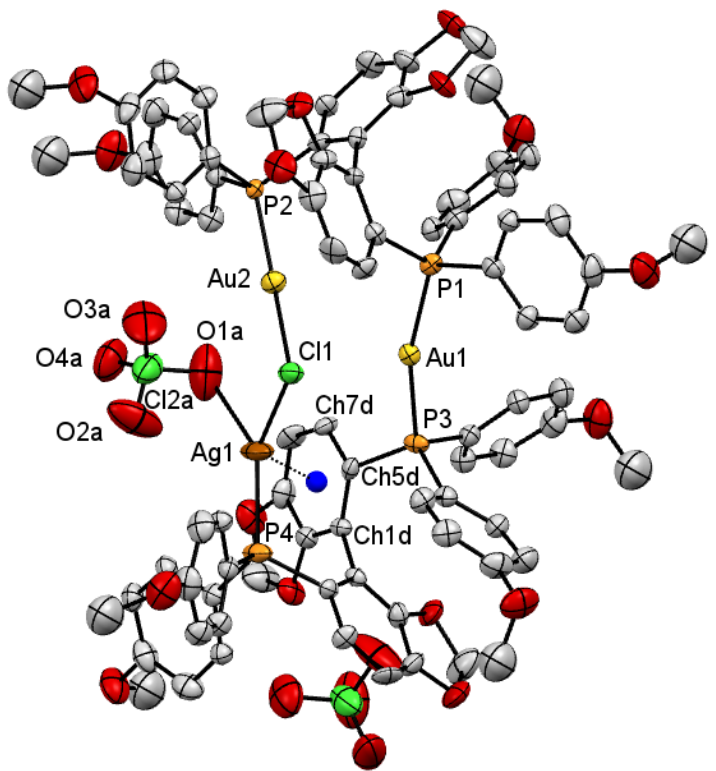

Figure 5. Molecular structure of complex $3 \mathbf{e}$ at the solid state. Thermal ellipsoids are shown at the $50 \%$ probability level. Hydrogens atoms and tBu groups were omitted for clarity. Selected bond lengths $(\AA)$ : Au1-Au2 3.552(19), P1-Au1 2.314(2), P2-Au2 2.242(2), P3-Au1 2.321(3), Au2-Cl1 2.345(2), Cl1-Ag1 2.552(3), Ag1-P4 2.373(2), Ag1-O1a 2.464(19), Au1 Ag1 4.160(19), Ag1-Ch1d 3.233(19), Ag1-Ch5d 2.705(19), Ag1-Ch7d 2.901(19), Ag1-blue centroid 3.100(19). CCDC 1539524.

Both complexes had two gold atoms which were not coordinated to each other or to perchlorate anions, and whose coordination appeared to be different from 3 b (Figures 4-5, Figures S8 and S10). Indeed, we observed two (S)-DTBM-Segphos ligands were coordinated to the two gold atoms in a trans-fashion. It was worth to note a similar species was formed while using silver hexafluoroantimonate (Figure S9). As compared to complex 3d, $X$-ray diffraction analysis of species $3 \mathbf{e}$ showed an additional silver chloride molecule inserted into one of the phosphorousgold bonds (Figures 5 and S10). Whereas silver chloride was once shown to form a triangular fragment with a gold(I) NHC complex, ${ }^{[7]]}$ species $3 e$ highlighted for the first time a rather linear adduct, gold and silver being connected through a $\mu$-chloro bridge and coordinated to two distinct phosphorous atoms. It was worth to note the coordination geometry of the silver centre was likely trigonal pyramidal as this metal was also bound to an oxygen of a perchlorate anion and to aromatic carbons through pi-stacking interactions, a silver-centroid distance of average 3.100(19) ^ being measured (Figure 5). In the past, several silver chloride adducts were characterised for $\operatorname{gold}(\mathrm{I}),{ }^{[6,7]]}$ iridium(I) ${ }^{[24]}$ and platinum(II) complexes. ${ }^{[25]}$

As monocationic binuclear complexes were shown to be preferred in the case of the intramolecular hydroalkoxylation of allenes, ${ }^{[26]}$ we subsequently investigated the synthesis of monocationic binuclear gold complex $3 f$ through the use of a single equivalent of silver perchlorate (Scheme 4, Figures S11S13).

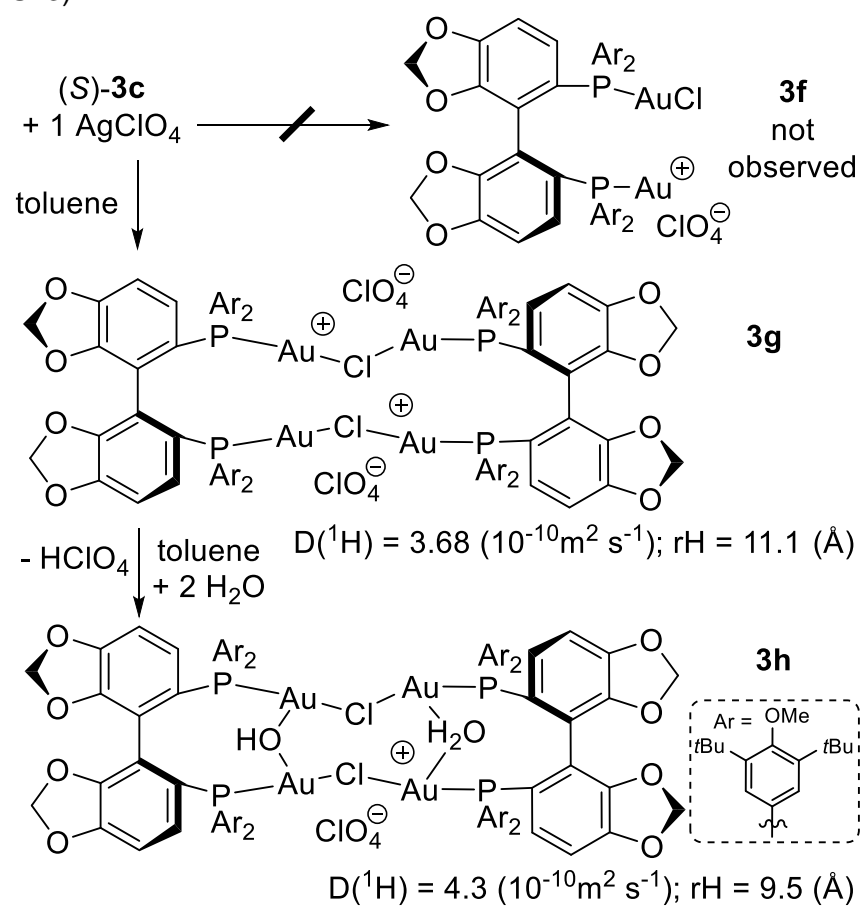

Scheme 4. Synthesis of gold(I) cationic complexes $\mathbf{3 g}$ and $\mathbf{3 h}$.

To our surprise, we isolated complexes $\mathbf{3 g}$ and $\mathbf{3 h}$ as the result of a self-assembly of two species $\mathbf{3 f}{ }^{[27]}$ For $\mathbf{3 g}$, both (S)-DTBMSegphos ligands were respectively coordinated to two gold atoms and the resulting complexes were connected to each other through two $\mu$-chloro bridges. Compound $\mathbf{3 h}$ had a related but more rigid molecular structure than $\mathbf{3 g}$ thanks to the additional hydroxyl and aquo bridges linking the gold atoms. Whether we were unable to get any suitable crystals for X-ray diffraction analysis, DOSY ${ }^{1} \mathrm{H}$ NMR experiments confirmed clearly compounds with higher molecular volumes and weight than $\mathbf{3 f}$ were formed. Indeed, lower diffusion coefficients $D$ and higher hydrodynamic radii $\mathrm{rH}$ were observed for $\mathbf{3 g}$ and the rigid $\mathbf{3 h}$ as compared to $\mathbf{3 f}$ whose $\mathrm{D}$ and $\mathrm{rH}$ values would have been close from complexes 3a-c (Scheme 4, Table 5). 
Mass spectrometry and other analyses confirmed $\mathbf{3 g}$ and $\mathbf{3 h}$ complexes were obtained and, similar species were formed while using silver hexafluoroantimonate (Figure $\mathrm{S} 13$ and other supporting informations). Finally, it was worth to note complexes $\mathbf{3 g}$ and $\mathbf{3 h}$ were far less efficient catalysts for the hydroamination of amino-alkene 1 (Figure S12).

Following these rather unexpected results, dinuclear gold perchlorate catalyst complex $\mathbf{3} \mathbf{a}$ was analysed in methanol by ESI-FT mass spectrometry (Figure 4, figures S14-S19). Two monocationic gold complexes, respectively binuclear and mononuclear, were first identified along with some oxidised ligand. We further noticed a good agreement of experimental and simulated isotopic ratios for the chlorinated binuclear species (Figures S16-S19). Moreover, the expected dicationic gold species was not detected at $\mathrm{m} / \mathrm{z} 786.745$ and a silverchloride adduct of a binuclear monocationic gold complex was observed. In order to check whether the observed species could be affected by the solvent and the ionisation mode, additional analyses of complex 3a were performed in toluene using a mass spectrometer coupled with an additional Liquid Injection Field Desorption lonization (LIFDI) source (Figures S20-S21). ${ }^{[28]}$

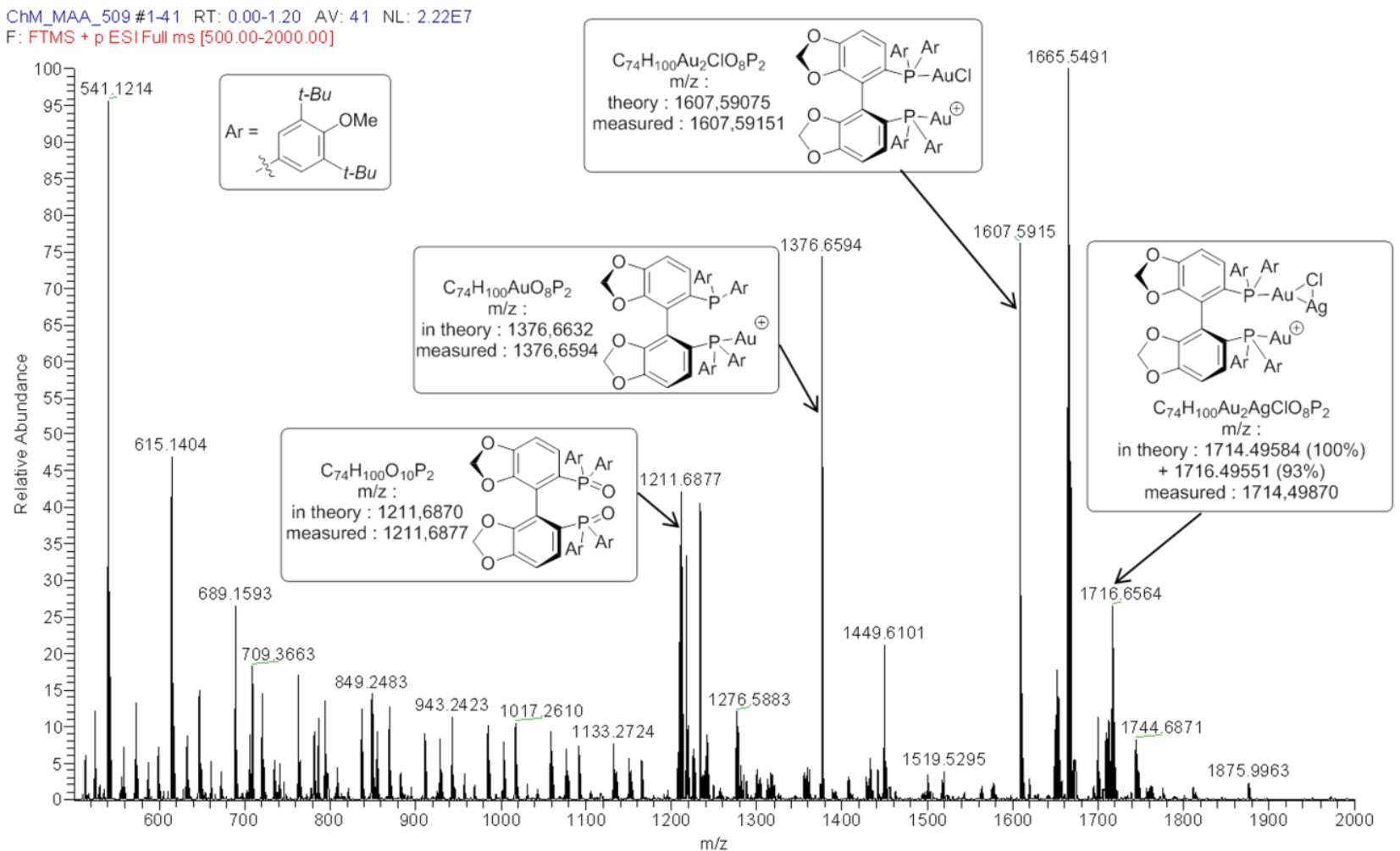

Figure 6. Mass spectrum of compound 3a in methanol.

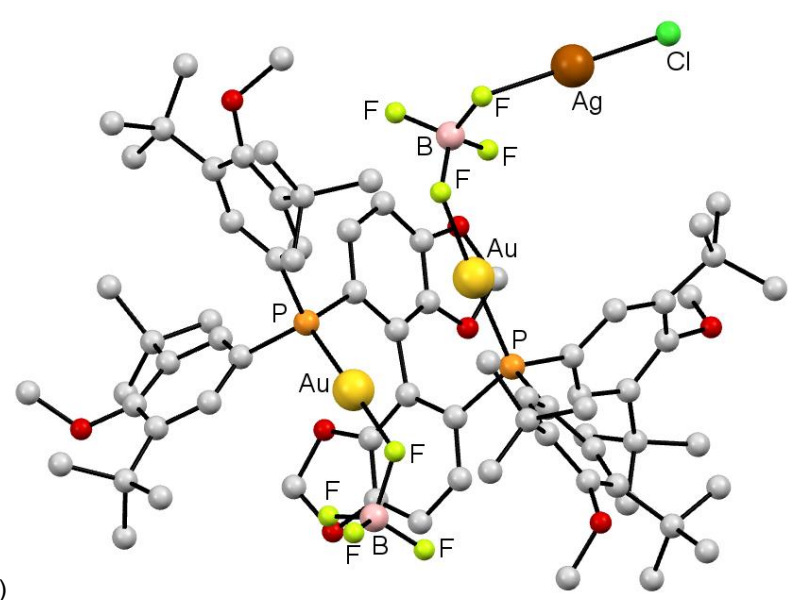

b)

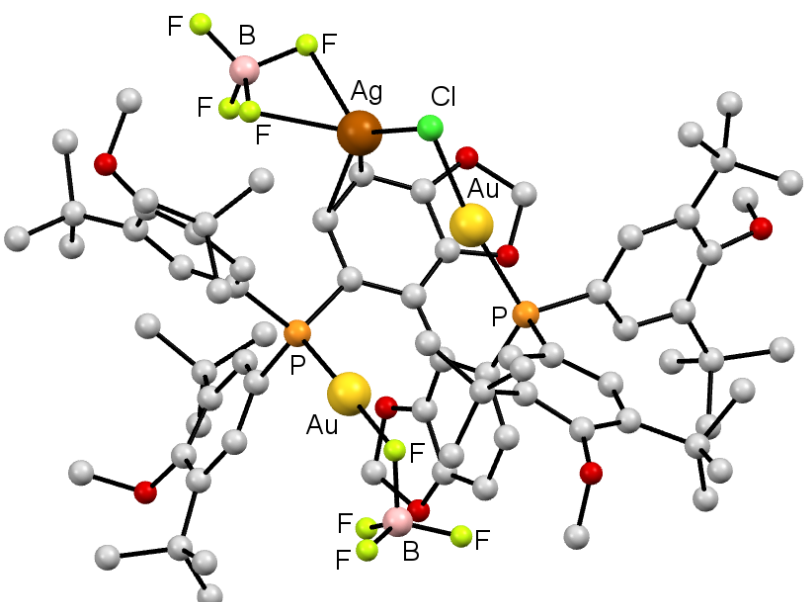

Figure 7. Optimized structures of two possible silver chloride adducts of compound $\mathbf{3 b}$. Hydrogen atoms are omitted for clarity. a) silver chloride interacting only with one of the tetrafluoroborate anions; b) silver coordinating to a tetrafluoroborate anion and to two aromatic carbons of the phosphine ligand as well as direct bonding of the chloride atom to one of the gold centres.

The resulting mass spectra were in good agreement with the ESI-MS data as two binuclear monocationic gold complexes were observed, one gold atom being bound either to a chloride, either to a perchlorate anion. In addition, similar isotope distributions were observed for measured and simulated spectra

At that stage, though mass spectrometry had already allowed identification of several transient gold species, ${ }^{[29]}$ we remained careful about drawing a parallel between a mass analysis and a solution phase synthesis or catalysis. 
Two possible silver chloride adducts of complex $\mathbf{3 b}$ (Figure 7) were investigated by DFT calculations at the B3PW91 level of theory. A first adduct was found in which silver chloride interacts only with one of the tetrafluoroborate anions (Figure 7a) but also a second one resulting from the direct bonding of the chloride atom to one of the gold centres together with the coordination of the silver atom to a tetrafluoroborate (Figure $7 \mathrm{~b}$ ), the latter being the more stable one by $12.3 \mathrm{kcal}^{\mathrm{mol}}{ }^{-1}$ (Gibbs free energy). The energy difference between these two complexes can be explained by the second-order perturbation of the NBO's analysis which highlights the formation of two stabilising interactions, between the chloride atom and the gold atom (donation from a chloride lone pair to an anti-bonding Au-P orbital) and between the silver atom and two aromatic carbons of the phosphine ligand (donation from the $\pi \mathrm{C}-\mathrm{C}$ bond to an empty $s$ orbital of silver). These stabilising interactions counterbalance the breaking of the interaction between a tetrafluoroborate anion and a gold atom. By comparison, the interaction mode of silver chloride in complex $3 e$ (Figure 5) was also theoretically studied. In this case, a decrease of the interaction between $\mathrm{Ag}$ and $\mathrm{Cl}$ is observed as evidenced by the elongation of the $\mathrm{Ag}-\mathrm{Cl}$ bond in $3 \mathrm{e}$ with respect to the most stable adduct $3 \mathbf{b}$ (2.552 and $2.438 \AA$ resp.). This is in agreement with the decrease of the donation of the chloride lone pairs to an empty $s$ orbital of the silver atom $\left(18 \mathrm{kcal}^{\mathrm{mol}}{ }^{-1}\right.$ for $3 \mathrm{e} v \mathrm{vs} .47$ $\mathrm{kcal} . \mathrm{mol}^{-1}$ for $3 \mathbf{b}$ ). According to second order perturbation NBO analysis, this difference is due to: $(I)$ the formation of a strong stabilising interaction (donation from a chloride lone pair to one of the gold centres, yielding a stabilisation energy of $83 \mathrm{kcal} . \mathrm{mol}$ ${ }^{1}$ that is slightly higher than the $70 \mathrm{kcal}^{\mathrm{mol}}{ }^{-1}$ found for $3 \mathbf{b}$ ); (ii) the stabilisation of the silver atom in complex $3 \mathbf{e}$ due to the donation from a phosphorous lone pair to an empty $s$ orbital of the silver atom $\left(85 \mathrm{kcal}^{\mathrm{mol}}{ }^{-1}\right)$ and from a lone pair of one of the oxygen atoms of a perchlorate anion to an empty $s$ orbital of the silver atom $\left(14 \mathrm{kcal}^{\mathrm{mol}}{ }^{-1}\right)$.

Analyses by $\mathrm{X}$-ray fluorescence spectrometry were performed on catalyst 3a solutions after decantation of silver chloride residues (Figures S22-S23). Whether no silver was present in toluene, methanol solutions of catalyst $3 \mathbf{a}$ proved to contain silver and gold in a 1:2 ratio. Hence, the use of methanol allowed the solvation of silver chloride and could favour the formation of a silver adduct on the basis of catalysts $\mathbf{3 a}$ or $\mathbf{3 b}$ (Figure 7 ) or like complex $\mathbf{3 e}$ (Scheme 3 , Figure 5).

Considering the reaction mechanism hypothesis (Scheme 5), the first step shall be the electrophilic activation of the alkene by the gold catalyst followed by the nucleophilic attack of the amine which was previously found to be reversible. ${ }^{[30-33]}$ Second, the tautomerization of the resulting carbamate intermediate is likely to be assisted by an anion (perchlorate in our case). ${ }^{[34,35]}$ Finally, the stereochemical outcome of the hydroamination reaction appeared to be defined during the final protodeauration $\operatorname{ste}^{[30]}$ by differentiation of the two assumed diastereomeric intermediates depending on the solvent used (Scheme 5). Because the use of toluene, a low polarity solvent, would imply the absence of gold-silver chloride adducts and lead to tight ion-pairs, a single gold metal might be bound to the aminated substrate with a possible gold-gold interaction as suggested by the structure of $3 \mathbf{c}$ at the solid state (Figure S7). ${ }^{[4 b, 36]}$ As a result, the proton-transfer/protodeauration step shall be assisted by the anion ${ }^{[34,35]}$ and affords the $(S)$-product.

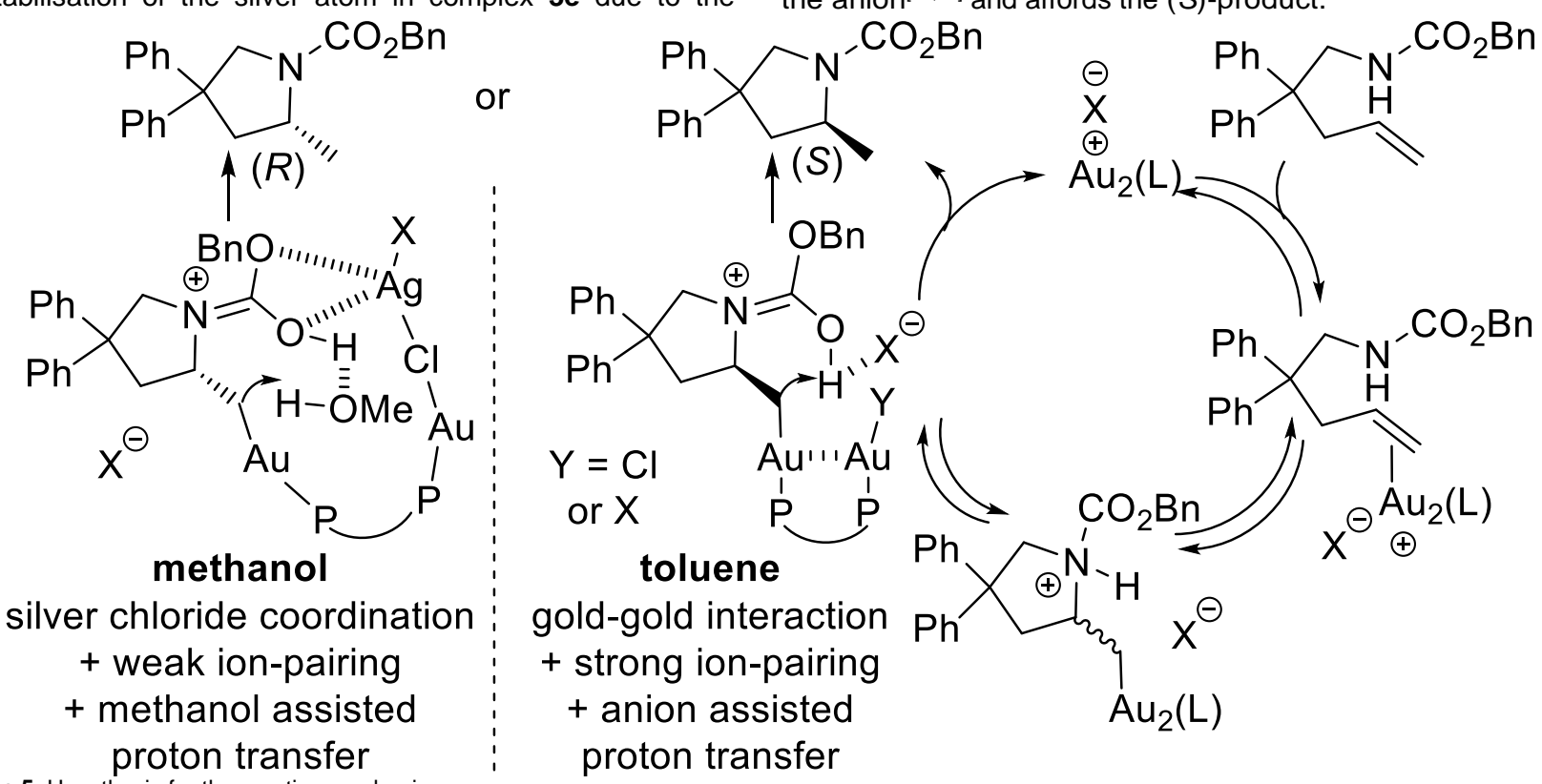

Scheme 5. Hypothesis for the reaction mechanism.

As opposed, methanol, a high polarity solvent, might allow the presence of gold-silver chloride adducts with possible wider bite angles and weak molecular ion-pairs. Whereas methanol itself shall act as a proton transfer agent for the protodeauration step as suggested by the strong isotopic effect observed when deuterated methanol was used, ${ }^{[14]}$ the aminated substrate might interact twice with a flexible gold / gold-silver species, the single gold atom being bound to the alkene moiety and the more oxophilic gold-silver adduct ${ }^{[32]}$ interacting with the carbamate function. Such proximal and bimetallic activation ${ }^{[4 b]}$ would allow the generation of the $(R)$-product and therefore lead to the enantioinversion. Hence, the protodeauration step would imply two different intermediates by presenting the $\mathrm{CH}_{2}$-Au group on one or the other face of the medium plane defined by the $\mathrm{N}$ heterocycle and by taking into account steric constrains of the overall molecular structure of the catalytic intermediate. As a result, this leads to the observed opposite stereochemistries. 


\section{Conclusions}

To summarise, when combined with silver perchlorate, a selected binuclear gold(I) chloride complex based on DTBM-Segphos ligand catalysed efficiently the asymmetric intramolecular hydroamination of alkenes at mild temperatures in presence of water with high yields and enantioselectivities. For the first time, both enantiomers of the products were obtained through the use of a single chiral gold catalyst by simply switching from toluene to methanol. Whereas the same first-order kinetic rate law with respect to substrate concentration was observed in methanol and toluene, analyses by $X$-ray fluorescence spectrometry showed only solutions of gold catalyst in methanol contained silver and gold in a 1:2 ratio. Whether several gold(I) cationic catalysts were characterised unambiguously at the solid state by X-ray analysis and in solution by diffusion NMR experiments, related silver chloride adducts were observed by ESI-MS and X-ray diffraction analysis and studied by DFT calculations. As opposed to toluene, methanol, a high polarity solvent, allows the presence of gold-silver adducts with wider bite angles and weak molecular ion-pairs. As a result, a flexible gold / gold-silver species may interact in a dual fashion with the aminated substrate. Indeed, through a double activation process, one single gold atom would be bound to the alkene moiety like in toluene and the more oxophilic goldsilver adduct would interact with the carbamate function. Hence, by comparison to toluene, methanol allows another selectivity to proceed among the two diastereomeric intermediates during the final protodeauration step and leads to the opposite enantiomer.

\section{Experimental Section}

Safety concern. Caution! Perchloric acid as well as all organic and organometallic perchlorate salts are often explosive and are thus highly dangerous. ${ }^{[37]}$

\section{General Procedure for the catalysis}

In a glovebox, AuS(Me $)_{2} \mathrm{Cl}(0.01 \mathrm{mmol}, 2.95 \mathrm{mg})$ and (S)-DTBMSegphos $(0.005 \mathrm{mmol}, 5.90 \mathrm{mg})$ are disposed in a first Schlenk flask. Under a nitrogen atmosphere, dry dichloromethane $(1 \mathrm{~mL})$ is then added and the resulting mixture is stirred for 1 hour at room temperature. Afterwards, the solvent is evaporated under vacuum and the resulting solid is dried 30 minutes before addition of $\mathrm{AgClO}_{4}(0.009 \mathrm{mmol}, 1.87 \mathrm{mg})$ in a glovebox. Under a nitrogen atmosphere, dry toluene or methanol $(1 \mathrm{~mL})$ is added and the resulting solution is stirred for 30 minutes before being transferred to a second Schlenk flask containing the corresponding substrate $(0.18 \mathrm{mmol})$. Finally, $\mathrm{H}_{2} \mathrm{O}(0.28 \mathrm{mmol}, 5$ $\mu \mathrm{L})$ is added under nitrogen to the reaction mixture. After 20 hours under stirring at $50{ }^{\circ} \mathrm{C}$, the solution is filtered through a pad of silica gel using dichloromethane as solvent. After evaporation of solvents under vacuum, the resulting oil is analysed by ${ }^{1} \mathrm{H}$ NMR and HPLC.

\section{Computational details}

All calculations were performed with Gaussian 09. [38] Calculations were carried out at the DFT level of theory using the hybrid functional B3PW91. ${ }^{[39]}$ Geometry optimizations were achieved without any symmetry restriction. Calculations of vibrational frequencies were systematically done in order to characterize the nature of stationary points. Stuttgart effective core potentials ${ }^{[40]}$ and their associated basis set were used for gold, silver and chlorine. The basis sets were augmented by a set of polarization functions $\left(\zeta_{\mathrm{f}}=1.050\right.$ for $\mathrm{Au}, \zeta_{\mathrm{f}}=1.611$ for $\mathrm{Ag}$ and $\zeta_{\mathrm{d}}=0.6433$ for $\mathrm{Cl}$ ). Boron, fluorine, phosphorus, oxygen, carbon and hydrogen atoms were treated with $6-31 \mathrm{G}(\mathrm{d}, \mathrm{p})$ double- $\zeta$ basis sets. ${ }^{[41]}$ The electron density and partial charge distribution were examined in terms of localized electron-pair bonding units by using the NBO program implemented in Gaussian 09. ${ }^{[42]}$

\section{Acknowledgements}

We thank ANR (ANR-09-BLAN-0032-02 with a PhD fellowship to F.M), The University of Lille 1 is acknowledged for a PhD fellowship to M.-A. A. The CNRS, the Chevreul Institute (FR 2638), the Ministère de l'Enseignement Supérieur et de la Recherche, the Région Hauts-de-France and the FEDER are acknowledged for supporting and funding partially this work. Mrs Catherine Méliet and Céline Delabre (UCCS) are thanked for elemental analyses and HPLC analyses. Pr. Christophe Dujardin and Mr. JeanCharles Morin (UCCS) are thanked for some infra-red and far infra-red and Raman spectra and related discussions. Dr. Florian Albrieux (Univ. Claude Bernard Lyon 1 / IFPen) is thanked for preliminary CSI-MS analyses. Dr. Stephan Wagner (Inorg. Chem. Dpt. Univ. Würzburg, Germany) is acknowledged for granting us access to an Exactive Orbitrap mass spectrometer. Dr. Uwe Linne (Univ. Marburg, Germany) is acknowledged for granting us access to an AccuTOF mass spectrometer.

Keywords: alkene • enantiodivergent catalysis • gold • hydroamination $\cdot$ silver.

[1] a) J. J. Brunet, D. Neibecker, in Catalytic Heterofunctionalization from Hydroamination to Hydrozirconation, (Eds.: Togni, A.; Grutzmacher, H.), Wiley-VCH: Weinheim, Germany, 2001, pp. 10; b) S. Doye, in Science of Synthesis, Vol. 40a, (Eds.: Enders, D.; Schaumann, E.), Thieme: Stuttgart, 2009, pp. 241; c) A. D. Sadow, in Comprehensive Inorganic Chemistry II, J. Reedijk and K. Poeppelmeier (Eds), 2013, vol 6, 487 520; d) T. E. Müller, M. Beller, Chem. Rev. 1998, 98, 675; e) I. Bytschkov, S. Doye, Eur. J. Org. Chem. 2003, 935; f) K. C. Hultzsch, Adv. Synth. Catal. 2005, 347, 367; g) I. Aillaud, J. Collin, J. Hannedouche, E. Schulz, Dalton Trans. 2007, 36, 5105; h) T. E. Mueller, K. C. Hultzsch, M. Yus, F. Foubelo, M. Tada, Chem. Rev. 2008, 108, 3795; i) S. R. Chemler Org. Biomol. Chem. 2009, 7, 3009; j) U. M. Dzhemilev, G. A. Tolstikov, R. I. Khusnutdinov, Russ. J. Org. Chem. 2009, 45, 957; k) J. Hannedouche, E. Schulz, Chem. Eur. J. 2013, 19 4972; I) A. L. Reznichenko, A. J. Nawara-Hultzsch, K. C. Hultzsch, Top. Curr. Chem. 2014, 343, 191; m) L. Huang, M. Arndt, K. Gooßen, H Heydt, L. J. Gooßen, Chem. Rev. 2015, 115, 2596; n) E. Bernoud, C. Lepori, M. Mellah, E. Schulz, J. Hannedouche, Catal. Sci. Technol. 2015, 5, 2017; o) V. Rodriguez-Ruiz, R. Carlino, S. Bezzenine-Lafollée, R. Gil, D. Prim, E. Schulz, J. Hannedouche, Dalton Trans. 2015, 44, 
12029; p) C. Michon, M.-A. Abadie, F. Medina, F. Agbossou-Niedercorn, J. Organomet. Chem. 2017, DOI:10.1016/j.jorganchem.2017.03.032.

[2] For reviews on gold catalysis in racemic and asymmetric reactions: a) $Y$. Li, W. Li, J. Zhang, Chem. Eur. J. 2017, 23, 467; b) M. N. Hopkinson, A Tlahuext-Aca, F. Glorius Acc. Chem. Res. 2016, 49, 2261; c) A. Blanc, V. Bénéteau, J.-M. Weibel, P. Pale, Org. Biomol. Chem. 2016, 14 9184; d) J. Miro, C. del Pozo, Chem. Rev. 2016, 116, 11924; e) S. Kramer, Chem. Eur. J. 2016, 22, 15584; f) A. L. Siva Kumari, A. Siva Reddy, K. C. K. Swamy, Org. Biomol. Chem. 2016, 14, 6651; g) R. J. Harris, R. A. Widenhoefer, Chem. Soc. Rev. 2016, 45, 4533; h) M. R Fructos, M. M. Diaz-Requejo, P. J. Perez, Chem. Commun. 2016, 52, 7326; i) A. Quintavalla, M. Bandini, ChemCatChem 2016, 8, 1437; j) Y Wei, M. Shi, ACS Catal. 2016, 6, 2515; k) Z. Zheng, Z. Wang, Y. Wang L. Zhang, Chem. Soc. Rev. 2016, 45, 4448, I) L. Liu, J. Zhang, Chem. Soc. Rev. 2016, 45, 506; m) C. Bour, V. Gandon, Synlett 2015, 26, 1427; n) D. Qian, J. Zhang, Chem. Soc. Rev. 2015, 44, 677; o) S Ferrer, M. E. Muratore, A. M. Echavarren, ChemCatChem 2015, 7, 228; p) B. Ranieri, I. Escofeta, A. M. Echavarren, Org. Biomol. Chem. 2015, 13, 7103; q) D. Weber, M. R. Gagne, Top. Current Chem. 2015, 357, 167; r) D. Malhotra, G. B. Hammond, D. Xu, Top. Current Chem. 2015 357, 1; s) V. Michelet, Top. Current Chem. 2015, 357, 95; t) P. H. S. Paioti, A. Aponick, Top. Current Chem. 2015, 357, 63; u) S. M. Inamdar, A. Konala, N. T. Patil, Chem. Commun. 2014, 50, 15124; v) Y.-M. Wang, A. D. Lackner, F. D. Toste Acc. Chem. Res. 2014, 47, 889; w) A Fürstner Acc. Chem. Res. 2014, 47, 925; x) X. Liu, L. He, Y.-M. Liu, Y Cao, Acc. Chem. Res. 2014, 47, 793; y) J. Xie, C. Pan, A. Abdukader C. Zhu, Chem. Soc. Rev. 2014, 43, 5245; z) A. Pradal, P. Y. Toullec, V. Michelet, Synthesis 2011, 1501.

[3] About gold catalysis with C-C multiple bond substrates: a) A. S. K. Hashmi, Chem. Rev. 2007, 107, 3180; b) D. J. Gorin, B. D. Sherry, F. D. Toste, Chem. Rev. 2008, 108, 3351; c) R. A. Widenhoefer, Chem. Eur. J. 2008, 14, 5382; d) N. T. Patil, V. Singh, J. Organomet. Chem. 2011, 696, 419; e) M. Rudolph, A. S. K. Hashmi, Chem. Commun. 2011, 47 6536; f) D. Garayalde, C. Nevado, ACS Catal. 2012, 2, 1462; g) M. Chiarucci, M. Bandini, Beilstein J. Org. Chem. 2013, 9, 2586; h) M. E. Muratore, A. Homs, C. Obradors, A. M. Echavarren, Chem. Asian J. 2014, 9, 3066; i) W. Debrouwer, T. S. A. Heugebaert, B. I. Roman, C. V. Stevens, Adv. Synth. Cat. 2015, 357, 2975; j) A. C. Jones, Top. Current Chem. 2015, 357, 133; k) R. Dorel, A. M. Echavarren, J. Org. Chem. 2015, 80, 7321; I) R. Dorel, A. M. Echavarren, Chem. Rev. 2015, 115 9028; m) J. A. Goodwin, A. Aponick, Chem. Commun. 2015, 51, 8730; n) A; M. Asiri, A. S. K. Hashmi, Chem. Soc. Rev. 2016, 45, 4471; o) D. P. Day; P. W. H. Chan, Adv. Synth. Catal. 2016, 358, 1368; p) D. B. Huple, S. Ghorpade, R. S. Liu, Adv. Synth. Catal. 2016, 358, 1348; q) S. Nayak, B. Prabagar, A. K. Sahoo, Org. Biomol. Chem. 2016, 14, 803.

[4] a) Z. Zhang, S. D. Lee, R. A. Widenhoefer, J. Am. Chem. Soc. 2009, 131, 5372; b) M. Kojima, K. Mikami, Synlett 2012, 23, 57; c) Y. W. Sun, Q. Xu, M. Shi, Beilstein J. Org. Chem. 2013, 9, 2224; d) S. D. Lee, J. C. Timmerman, R. A. Widenhoefer, Adv. Synth. Catal. 2014, 356, 3187; e) C. Michon, M.-A. Abadie, F. Medina, F. Agbossou-Niedercorn, Catalysis Today 2014, 235, 2; f) M.-A. Abadie, F. Medina, F. Agbossou-Niedercorn, C. Michon, Chimica OGGI - Chemistry Today 2014, 32, 19; g) M.-A. Abadie, X. Trivelli, F. Medina, F. Capet, P. Roussel, F. Agbossou-Niedercorn, C. Michon, ChemCatChem 2014, 6, 2235.

[5] a) C. Michon, F. Medina, F. Capet, P. Roussel, F. AgbossouNiedercorn, Adv. Synth. Catal. 2010, 352, 3293; b) F. Medina, C. Michon, F. Agbossou-Niedercorn, Eur. J. Org. Chem. 2012, 6218; c) C. Michon, F. Medina, M.-A. Abadie, F. Agbossou-Niedercorn, Organometallics 2013, 32, 5589.

[6] About "silver effect" on gold catalysis: a) D. Weber, M. R. Gagné, Org. Lett. 2009, 11, 4962; b) S. R. Patrick, I. I. F. Boogaerts, S. Gaillard, A. M. Z. Slawin, S. P. Nolan, Beilstein J. Org. Chem. 2011, 7, 892; C) D. Wang, R. Cai, S. Sharma, J. Jirak, S. K. Thummanapelli, N. G. Akhmedov, H. Zhang, X. Liu, J. L. Petersen, X. Shi, J. Am. Chem. Soc. 2012, 134, 9012; d) Y. Zhu, C. S. Day, L. Zhang, K. J. Hauser, A. C. Jones, Chem. Eur. J. 2013, 19, 12264; e) A. Homs, I. Escofet, A. M. Echavarren, Org. Lett. 2013, 15, 5782; f) A. Guérinot, W. Fang, M. Sircoglou, C. Bour, S. Bezzenine-Lafollée, V. Gandon, Angew. Chem.
2013, 125, 5960; Angew. Chem. Int. Ed. 2013, 52, 5848; g) Y. Su; M Lu, B. Dong, H. Chen, X. Shi; Adv. Synth. Catal. 2014, 356, 692; h) W. Fang, M. Presset, A. Guérinot, C. Bour, S. Bezzenine-Lafollée, V. Gandon, Chem. Eur. J. 2014, 20, 5439; i) A. Zhdanko, M. E. Maier ACS Catal. 2015, 5, 5994; j) G. Xu, K. Liu, Z. Dai, J. Sun, Org. Biomol. Chem. 2017, 15, 2345

[7] a) R. Uson, A. Laguna, M. V. Castrillo, Synth. React. Inorg. Met.Org.Chem. 1979, 9, 317; b) A. Bayler, A. Bauer, H. Schmidbaur Chem. Ber. 1997, 130, 115; c) A. Hamel, N. W. Mitzel, H. Schmidbaur, J. Am. Chem. Soc. 2001, 123, 5106; d) H. Schmidbaur, A. Hamel, N. W. Mitzel, A. Schier, S. Nogai, Proc. Natl. Acad. Sci. USA 2002, 99, 4916; e) K. Zhang, J. Prabhavathy, J. H. K. Yip, L. L. Koh, G. K. Tan, J. J. Vittal, J. Am. Chem. Soc. 2003, 125, 8452; f) S. G. Weber, F. Rominger, B. F. Straub, Eur. J. Inorg. Chem. 2012, 2863.

[8] a) H. Buschmann, H.-D. Scharf, N. Hoffmann, P. Esser, Angew. Chem Int. Ed. 1991, 30, 477-515; Angew. Chem. 1991, 103, 480; b) G. Zanoni, F. Castronovo, M. Franzini, G. Vidari, E. Giannini, Chem. Soc Rev. 2003, 32, 115; c) T. Tanaka, M. Hayashi, Synthesis 2008, 3361; d) G. Cainelli, P. Galletti, D. Giacomini, Chem. Soc. Rev. 2009, 38, 990; e) M. Bartûk, Chem. Rev. 2010, 110, 1663; f) J. Escorihuela, M. I. Burguete, S. V. Luis, Chem. Soc. Rev. 2013, 42, 5595; g) J. Burés, P. Dingwall, A. Armstrong, D. G. Blackmond, Angew. Chem. Int. Ed. 2014, 53, 8700; Angew. Chem. 2014, 126, 8844; h) G. Storch, O. Trapp, Angew. Chem. Int. Ed. 2015, 54, 3580; Angew. Chem. 2015, 127 3650; i) V. Blanco, D. A. Leigh, V. Marcos, Chem. Soc. Rev. 2015, 44, 5341; j) P. Oczipka, D. Mueller, W. Leitner, G. Francio, Chem. Science 2016, 7, 678; k) I. Mendez, R. Rodriguez, V. Polo, V. Passarelli, F. J. Lahoz, P. Garcia-Orduna, D. Carmona, Chem. Eur. J. 2016, 22, 11064 I) G. Foli, C. S. D'Elia, M. Fochi, L. Bernardi, RSC Adv. 2016, 6, 66490; m) C.-T. Chen, C. C. Tsai, P.-K. Tsou, G.-T.Huang, C.-H. Yu, Chem Science 2017, 8, 524; n) A. Matusmoto, S. Fujiwara, Y. Hiyoshi, K. Zawatzky, A. A. Makarov, C. J. Welch, K. Soai, Org. Biomol. Chem. 2017, 15, 555

[9] a) R. Saito, S. Naruse, K. Takano, K. Fukuda, A. Katoh, Y. Inoue, Org. Lett. 2006, 8, 2067; b) V. S. Chan, M. Chiu, R. G. Bergman, F. D. Toste, J. Am. Chem. Soc. 2009, 131, 6021; c) Y. Sohtome, S. Tanaka, K. Takada, T. Yamaguchi, K. Nagasawa, Angew. Chem. Int. Ed. 2010, 49, 9254; Angew. Chem. 2010, 122, 9440.

[10] For counterion-induced enantioinversion in gold catalysis: a) M. Bandini, M. Monari, A. Romaniello, M. Tragni, Chem. Eur. J. 2010, 16, 14272; b) M. Chiarucci, R. Mocci, L.-D. Syntrivanis, G. Cera, A. Mazzanti, M. Bandini, Angew. Chem. Int. Ed. 2013, 52, 10850; Angew. Chem. 2013 , 125, 11050

[11] For either solvent or counterion effect in gold catalysis: a) P. W. Davies, N. Martin, Org. Lett. 2009, 11, 2293; b) W. Fang, M. Presset, A. Guérinot, C. Bour, S. Bezzenine-Lafollée, V. Gandon, Org. Chem. Front. 2014, 1, 608; c) M. Jia, M. Bandini, ACS Catal. 2015, 5, 1638; d) F. Jaroschik, A. Simonneau, G. Lemière, K. Cariou, N. Agenet, H. Amouri, C. Aubert, J.-P. Goddard, D. Lesage, M. Malacria, Y. Gimbert, V. Gandon, L. Fensterbank, ACS Catal. 2016, 6, 5146.

[12] For a gold catalysed enantioinversion controlled by a protic solvent, a coordinating counterion or even by a second substrate molecule: M. K. Ilg, L. M. Wolf, L. Mantilli, C. Farès, W. Thiel, A. Fürstner, Chem. Eur. J. 2015, 21, 12279.

[13] a) W. Beck, K. Sünkel, Chem. Rev. 1988, 88, 1405; c) S. H. Strauss Chem. Rev. 1993, 93, 927; d) A. Macchioni, Chem. Rev. 2005, 105 2039; e) P. S. Pregosin, Pure Appl. Chem. 2009, 81, 615.

[14] a) J. Zhang, W. Shen, L. Li, M. Li, Organometallics 2009, 28, 3129; b) C. M. Krauter, A. S. K. Hashmi, M. Pernpointner, ChemCatChem 2010, 2, 1226.

[15] a) F. Lutz, T. Igarashi, T. Kinoshita, M. Asahina, K. Tsukiyama, T. Kawasaki, K. Soai, J. Am. Chem. Soc. 2008, 130, 2956; b) A. Nojiri, N Kumagai, M. Shibasaki, J. Am. Chem. Soc. 2009, 131, 3779; c) For an enantiodivergent catalyst showing non-linear effects: Z. Wang, Z. Yang, D. Chen, X. Liu, L. Lin, X. Feng, Angew. Chem. Int. Ed. 2011, 50, 4928; Angew. Chem. 2011, 123, 5030; d) For higher catalyst aggregation states inferred by other methods: G. Lu, T. Yoshino, H. Morimoto, S. Matsunaga, M. Shibasaki, Angew. Chem. Int. Ed. 2011, 50, 4382; 
Angew. Chem. 2011, 123, 4474; e) M. E. Noble-Teran, T. Buhse, J. M. Cruz, C. Coudret, J. C. Micheau, ChemCatChem 2016, 8, 1836.

[16] a) T. Satyanarayana, S. Abraham, H. B. Kagan, Angew. Chem. Int. Ed. 2009, 48, 456; Angew. Chem. 2009, 121, 464

[17] For anion- $\pi$ interactions with gold complexes: a) J.-Y. Hu, J. Zhang, G.-X. Wang, H.-L.Sun, J.-L. Zhang, Inorg. Chem.2016, 55, 2274; b) C. Garcia-Simon, M. Garcia-Borras, L. Gomez, I. Garcia-Bosch, S. Osuna, M. Swart, J. P. Luis, C. Rovira, M. Almeida, I. Imaz, D. Maspoch, M. Costas, X. Ribas, Chem. Eur. J. 2013, 19, 1445; c) K. Chen, C. E. Strasser, J. C. Schmitt, J. Shearer, V. J. Catalano, Inorg. Chem. 2012, 51, 1207; d) E. R. T. Tiekink, J. ZukermanSchpector, CrystEngComm 2009, 11, 1176.

[18] For cation- $\pi$ interactions with gold complexes: a) Q. Zhou, Y. Li, J. Am. Chem. Soc. 2014, 136, 1505; b) E. Herrero-Gómez, C. NietoOberhuber, S. López, J. Benet-Buchholz, A. M. Echavarren, Angew. Chem. 2006, 118, 5581; Angew. Chem., Int. Ed. 2006, 45, 5455.

[19] For general examples of anion- $\pi$ interactions: a) $Y$. Zhao, Y. Domoto, E. Orentas, C. Beuchat, D. Emery, J. Mareda, N. Sakai, S. Matile, Angew. Chem. 2013, 125, 10124; Angew. Chem. Int. Ed. 2013, 52, 9940; b) H. T. Chifotides, K. R. Dunbar, Acc. Chem. Res. 2013, 46, 894; c) Y. Zhao, C. Beuchat, Y. Domoto, J. Gajewy, A Wilson, J. Mareda, N. Sakai, S. Matile, J. Am. Chem. Soc. 2014 136, 2101.

[20] For general examples of cation- $\pi$ interactions: a) S. Yamada, J. S Fossey, Org. Biomol. Chem. 2011, 9, 7275; b) D. A. Dougherty, Acc. Chem. Res. 2013, 46, 885; c) A. S. Mahadevi, G. N. Sastry, Chem. Rev. 2013, 113, 2100.

[21] O. Kanno, W. Kuriyama, J. Z. Wang, D. F. Toste, Angew. Chem. 2011, 123, 10093 ; Angew. Chem. Int. Ed. 2011, 50, 9919

[22] a) Y. Tang, B. Yu, RSC Adv. 2012, 2, 12686; b) A. Zhdanko, M. Ströbele, M. E. Maier, Chem. Eur. J. 2012, 18, 14732; c) Y. Zhu, W. Zhou, E. M. Petryna, B. R. Rogers, C. S. Day, A. C. Jones, ACS Catal. 2016, 6, 7357

[23] N. Mézailles, L. Ricard, F. Gagosz, Org. Lett. 2005, 7, 4133.

[24] G. Sipos, P. Gao, D. Foster, B. W. Skelton, A. N. Sobolev, R. Dorta, Organometallics 2017, 36, 801.

[25] a) R. Usón, J. Forniés, B. Menjón, F. A. Cotton, L. R. Falvello, M. Tomás, Inorg. Chem. 1985, 24, 4651; b) R. Usón, J. Forniés, M. Tomás J. M. Casas, F. A. Cotton, L; R. Falvello, Inorg. Chem. 1986, 25, 4519; c) D. J. Liston, C. A. Reed, C. W. Eigenbrot, W. R. Scheidt, Inorg Chem. 1987, 26, 2739; d) R. Usón, J. Forniés, M. Tomás, I. Ara, J. M. Casas, Inorg. Chem. 1989, 28, 2388; e) Z. Xie, T. Jelínek, R. Bau, C. A Reed, J. Am. Chem. Soc. 1994, 116, 1907; f) D. S. Bohle, Z. Chua, Organometallics 2015, 34, 1074;

[26] K. Aikawa, M. Kojima, K. Mikami, Adv. Synth. Catal. 2010, 352, 3131.

[27] For examples: a) J.-M. Lehn, Comptes Rendus Chimie 2011, 14, 348; b) N. Lanigan; X. Wang, Chem. Commun. 2013, 49, 8133; c) F. Zhang, H. Li, Chem. Sci. 2014, 5, 3695; d) E. Peris, Chem. Commun. 2016, 52, 5777 .

[28] a) H. B. Linden, Eur. J. Mass Spectrom. 2004, 10, 459; b) Jürgen H. Gross, N. Nieth, H. B. Linden, U. Blumbach, F. J. Richter, M. E. Tauchert, R.Tompers and P. Hofmann, Anal .Bioanal. Chem. 2006, 386, 52; c) T. A. Dransfield, R. Nazir, R. N. Perutz, A. C. Whitwood, J. Fluorine Chem. 2010, 131, 1213

[29] a) R. Colton, K. L. Harrison, Y. A. Mah, J. C. Traeger Inorg. Chim. Acta 1995, 231, 65; b) A. Simonneau, F. Jaroschik, D. Lesage, M. Karanik, R. Guillot, M. Malacria, J.-C. Tabet, J.-P. Goddard, L. Fensterbank, V. Gandon, Y. Gimbert, Chem. Sci. 2011, 2, 2417; c) A. Zhdanko, M. E. Maier, Chem. Eur. J. 2013, 19, 3932; d) J. Schulz, E. Shcherbachenko, J. Roithová Organometallics 2015, 34, 3979.

[30] R. L. LaLonde, W. E. Brenzovich, D. Benitez, E. Tkatchouk, K. Kelley, W. A. Goddard III, F. D. Toste, Chem. Sci. 2010, 1, 226.

[31] The coordination of nitrogen atoms to gold has proven to be weak in several cases: a) X.-Y. Liu, Z. Guo, S. S. Dong, X.-H. Li, C.-M. Che, Chem. Eur. J. 2011, 17, 12932; b) M. Katari, M. N. Rao, G. Rajaraman, P. Ghosh, Inorg. Chem. 2012, 51, 5593; c) E. Alvarado, A. C. Badaj, T. G. Larocque, G. G. Lavoie Chem. Eur. J. 2012, 18, 12112.

[32] Gold(I) organometallics have appeared to be weak oxophilic species; see references about oxophilicity of gold and silver: a) A. Blanc, K.
Tenbrink, J. M. Weibel, P. Pale, J. Org. Chem. 2009, 74, 5342; b) Y. Su, Y. Zhang, N. G. Akhmedov, J. L. Petersen, X. Shi, Org. Lett. 2014, 16 2478; c) N. Morita, A. Yasuda, M. Shibata, S. Ban, Y. Hashimoto, I. Okamoto, O. Tamura, Org. Lett. 2015, 17, 2668.

[33] Well-defined cationic gold pi-alkene complexes containing triarylphosphine ligands have proven elusive if not handled at $-20^{\circ} \mathrm{C}$ or below: see R. E. M. Brooner, R. A. Windenhoefer, Angew. Chem. Int. Ed. 2013, 52, 11714

[34] G. Kovács, G. Ujaque, A. Lledós, J. Am. Chem. Soc. 2008, 130 853.

[35] The prominent role of counterions in proton transfer processes has been already described by several experimental and computational works: a) J. B. F. N. Engberts, B. Zwanenburg, Tetrahedron 1968 24, 1737; b) J. M. Hanckel, M. Y. Darensbourg, J. Am. Chem. Soc 1983, 105, 6979; c) L. N. Appelhans, D. Zuccaccia, A. Kovacevic, A R. Chianese, J. R. Miecznikowski, A. Macchioni, E. Clot, O. Eisenstein, R. H. Crabtree, J. Am. Chem. Soc. 2005, 127, 16299; d) D. L. Davies, S. M. A. Donald, S. A. Macgregor, J. Am. Chem. Soc. 2005, 127, 13754; e) D. García-Cuadrado, A. A. C. Braga, F. Maseras, A. M. Echavarren, J. Am. Chem. Soc. 2006, 128, 1066; f) M. G. Basallote, M. Besora, J. Duran, M. J. Fernández-Trujillo, A Lledós, M. A. Máñez, F. Maseras, J. Am. Chem. Soc. 2004, 126, 2320; g) M. G. Basallote, M. Besora, C. E. Castillo, M. J. FernándezTrujillo, A. Lledós, F. Maseras, M. A. Máñez, J. Am. Chem. Soc 2007, 129, 6608; h) H. Mishra, S. Enami, R. J. Nielsen, M. R. Hoffmann, W. A. Goddard III, A. J. Colussi, PNAS 2012, 109, 10228; i) D. Munz, M. Webster-Gardiner, R. Fu, T. Strassner, W. A Goddard III, T. B. Gunnoe, ACS Catalysis 2015, 5, 769.

[36] a) K. Aikawa, M. Kojima, K. Mikami, Angew. Chem. Int. Ed. 2009, 48, 6073; Angew. Chem. 2009, 121, 6189; b) S. Ito, M. Nanko, K. Mikami, Chem. Cat. Chem. 2014, 6, 2292; c) E. M. Barreiro, E. V. Boltukhina, A J. P. White, K. K. Hii, Chem. Eur. J. 2015, 21, 2686.

[37] Perchloric acid as well as all organic and organometallic perchlorate salts are often explosive and are thus highly dangerous. See: a) http://ehs.berkeley.edu/lessons-learned/lesson-learned-chemicalexplosion-causes-eye-injury;

b) https://www.ncsu.edu/ehs/CHP/PerchloricAcid section\%20ll.pdf c) www.gla.ac.uk/media/media_173314_en.pdf.

[38] Gaussian 09, Revision E.01, Frisch, M. J.; Trucks, G. W.; Schlegel, H. B.; Scuseria, G. E.; Robb, M. A.; Cheeseman, J. R.; Scalmani, G.; Barone, V.; Mennucci, B.; Petersson, G. A.; Nakatsuji, H.; Caricato, M.; Li, X.; Hratchian, H. P.; Izmaylov, A. F.; Bloino, J.; Zheng, G.; Sonnenberg, J. L.; Hada, M.; Ehara, M.; Toyota, K.; Fukuda, R.; Hasegawa, J.; Ishida, M.; Nakajima, T.; Honda, Y.; Kitao, O.; Nakai, H.; Vreven, T.; Montgomery, J. A., Jr.; Peralta, J. E.; Ogliaro, F.; Bearpark, M.; Heyd, J. J.; Brothers, E.; Kudin, K. N.; Staroverov, V. N.; Kobayashi, R.; Normand, J.; Raghavachari, K.; Rendell, A.; Burant, J. C.; Iyengar, S. S.; Tomasi, J.; Cossi, M.; Rega, N.; Millam, J. M.; Klene, M.; Knox, J. E.; Cross, J. B.; Bakken, V.; Adamo, C.; Jaramillo, J.; Gomperts, R.; Stratmann, R. E.; Yazyev, O.; Austin, A. J.; Cammi, R.; Pomelli, C.; Ochterski, J. W.; Martin, R. L.; Morokuma, K.; Zakrzewski, V. G.; Voth, G. A.; Salvador, P.; Dannenberg, J. J.; Dapprich, S.; Daniels, A. D. Farkas, Ö.; Foresman, J. B.; Ortiz, J. V.; Cioslowski, J.; Fox, D. J. Gaussian, Inc., Wallingford CT, 2009.

[39] a) A. D. Becke, Phys. Rev. A 1988, 38, 3098; b) J. P. Perdew, in Electronic structure of solids'91; Ed. P. Ziesche, H. Eschrig (Akademie Verlag, Berlin), 1991; c) P. Perdew, J. A. Chevary, S. H. Vosko, K. A. Jackson, M. R. Pederson, D. J. Singh, C. Fiolhais, Phys. Rev. B 1992 46, 6671; d) J. P. Perdew, J. A. Chevary, S. H. Vosko, K. A. Jackson, M. R. Pederson, D. J. Singh, C. Fiolhais, Phys. Rev. B 1993, 48, 4978; e) J. P. Perdew, K. Burke, Y. Wang, Phys. Rev. B 1996, 54, 16533; f) K. Burke, J. P. Perdew and Y. Wang, in Electronic Density Functional Theory: Recent Progress and New Directions, Ed. J. F. Dobson, G. Vignale, and M. P. Das (Plenum, 1998); Chapter Derivation of a Generalized Gradient Approximation: the PW91 Density Functional.

[40] a) D. Andrae, U. Haeussermann, M. Dolg, H. Stoll, H. Preuss, Theor. Chim. Acta 1990, 77, 123; b) A. Bergner, M. Dolg, W. Kuechle, H. Stoll, H. Preuss, Mol. Phys. 1993, 80, 1431. 
[41] a) R. Ditchfield, W. J. Hehre, and J. A. Pople, J. Chem. Phys. 1971, 54 724; b) W. J. Hehre, R. Ditchfield, J. A. Pople, J. Chem. Phys. 1972, 56 2257; c) P. C. Hariharan, J. A. Pople, Theor. Chem. Acc. 1973, 28, 213 d) P. C. Hariharan, J. A. Pople, Mol. Phys. 1974, 27, 209; e) M. M. Francl, W. J. Pietro, W. J. Hehre, J. S. Binkley, D. J. DeFrees, J. A Pople, M. S. Gordon, J. Chem. Phys. 1982, 77, 3654; f) T. Clark, J.
Chandrasekhar, G. W. Spitznagel, P. v. R. Schleyer, J. Comp. Chem 1983, 4, 294; g) M. J. Frisch, J. A. Pople, J. S. Binkley, J. Chem. Phys 1984, 80, 3265

[42] a) A. E. Reed, F. Weinhold, J. Chem. Phys. 1983, 78, 4066. b) A. E. Reed, L. A. Curtiss, F. Weinhold, Chem. Rev. 1988, 88, 899. 
